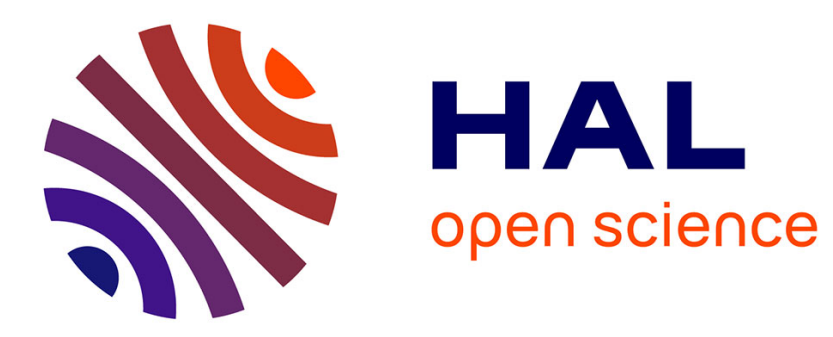

\title{
Neuronal selectivity of botulinum neurotoxins
}

Bernard Poulain, Emmanuel Lemichez, Michel Popoff

\section{To cite this version:}

Bernard Poulain, Emmanuel Lemichez, Michel Popoff. Neuronal selectivity of botulinum neurotoxins.

Toxicon, 2020, 178, pp.20-32. 10.1016/j.toxicon.2020.02.006 . pasteur-02491032

\section{HAL Id: pasteur-02491032}

\section{https://hal-pasteur.archives-ouvertes.fr/pasteur-02491032}

Submitted on 2 Mar 2020

HAL is a multi-disciplinary open access archive for the deposit and dissemination of scientific research documents, whether they are published or not. The documents may come from teaching and research institutions in France or abroad, or from public or private research centers.
L'archive ouverte pluridisciplinaire HAL, est destinée au dépôt et à la diffusion de documents scientifiques de niveau recherche, publiés ou non, émanant des établissements d'enseignement et de recherche français ou étrangers, des laboratoires publics ou privés.

\section{다)(1) $(5$}

Distributed under a Creative Commons Attribution - NonCommerciall 4.0 International 


\title{
NEURONAL SELECTIVITY OF BOTULINUM NEUROTOXINS
}

\author{
Bernard POULAIN ${ }^{1}$, Emmanuel LEMICHEZ ${ }^{2}$, Michel R. POPOFF ${ }^{2 *}$ \\ ${ }^{1}$ Institut des Neurosciences Cellulaires et Intégratives, (INCI)-CNRS, UPR 3212, Strasbourg, \\ France \\ ${ }^{2}$ Bacterial Toxins, Institut Pasteur, Paris, France \\ * Corresponding author: popoff2m@gmail.com
}

\begin{abstract}
Botulinum neurotoxins (BoNTs) are highly potent toxins responsible for a severe disease, called botulism. They are also efficient therapeutic tools with an increasing number of indications ranging from neuromuscular dysfunction to hypersecretion syndrome, pain release, depression as well as cosmetic application. BoNTs are known to mainly target motorneuron endings and to induce flaccid paralysis. BoNTs recognize a specific double receptor on neuronal cells consisting of gangliosides and synaptic vesicle protein, SV2 or synaptotagmin. Using cultured neuronal cells, BoNTs have been established blocking the release of a wide variety of neurotransmitters. However, BoNTs are more potent in motorneurons than in the other neuronal cell types. In in vivo models, BoNT/A impairs the cholinergic neuronal transmission at the motor-neurons but also at neurons controlling secretions and smooth muscle neurons, and blocks several neuronal pathways including excitatory, inhibitory, and sensitive neurons. However, only a few reports investigated the neuronal selectivity of BoNTs in vivo. In the intestinal wall, BoNT/A and BoNT/B target mainly the cholinergic neurons and to a lower extent the other non-cholinergic neurons including serotonergic, glutamatergic, GABAergic, and VIP-neurons. The in vivo effects induced by BoNTs on the non-cholinergic neurons remain to be precisely investigated. We report here a literature review of the neuronal selectivity of BoNTs.
\end{abstract}

KEY WORDS: Botulinum neurotoxin, neuronal cell, sensory neuron, ganglioside, synaptic vesicle protein 2 , synaptotagmin. enteric nervous system 


\section{INTRODUCTION}

Botulinum neurotoxins (BoNTs) are the most potent toxins among all bacteria, animal and plant toxins. Although they can block secretion process in a variety of cells, they have been called neurotoxins since at very low concentration they specifically interact with neuronal cells thereby inducing a blockade of neurotransmitter release. BoNTs are responsible for botulism in humans and other vertebrates. This disease is characterized by symptoms and manifestations due to decreased neurotransmission in the peripheral nervous system leading to flaccid paralysis, denoting attack of somatic nervous system, and to mild dysautonomia and constipation indicating alteration of the autonomic nervous system including its enteric part. The extremely high in vivo toxicity of BoNTs $(0.2-1 \mathrm{ng} / \mathrm{kg}$ body weight by parenteral route) results from a unique cascade of sequential steps leading to cumulative effects. The latter include trafficking from the intestinal tract to neuronal cells, recognition of specific neuronal cell receptors, receptor-mediated endocytosis followed by translocation into the cytosol of their catalytic domain (light $\mathrm{L}$ chain) that is a protease, and cleavage of SNARE proteins resulting in decreased neurotransmitter exocytosis at the nerve endings of the peripheral nervous system. Hence, partial blockade of acetylcholine release at neuromuscular junctions is sufficient to weaken respiratory and pharyngeal muscles so that respiratory insufficiency and asphyxia ensue (Poulain and Popoff, 2019). Given their extreme potency, BoNTs are considered among the most potent agents at risk of bioterrorism and are classified as a category A biothreat agent by the United States Centers of Disease Control and Prevention (Arnon et al., 2001; Smith, 2006). However, albeit several attempts of BoNT preparations as bioweapon such as in the first war in Iraq (Smith, 2006), no deleterious bioterrorism action has been reported. But, since the 1980's, and the pioneer studies from Alan Scott (Scott, 1981), type A and at a lesser extent B toxins have been widely used as therapeutic agents. The number of approved indications for them is growing and pertains to different medical domains as physical and rehabilitation medicine, neurology, ophtalmology, urology, pain medicine or aesthetic (Jankovic, 2017; Pirazzini and Rossetto, 2017; Pirazzini et al., 2017). All these indications exploit the very high selectivity of action of BoNT for neuronal cells. Therefore, this review focuses on their exquisite neuronal selectivity.

\section{Botulinum neurotoxins, diversity and structure}

On the basis of neutralization of the biological effects with specific antisera, notably using the mouse bioassay, BoNTs have been divided into 7 toxinotypes (A to G). Each typespecific antiserum only neutralizes the corresponding toxinotype. Since 20 years, progress in 
bacterial genome sequencing has revealed an amazing number of BoNT types and subtypes. A $8^{\text {th }}$ toxinotype called $\mathrm{H}$ (or $\mathrm{F} / \mathrm{A}$ or $\mathrm{H} / \mathrm{A}$ ) was identified in a bivalent $C$. botulinum strain isolated from an infant botulism case producing BoNT/B2 and BoNT/H (Barash and Arnon, 2014; Dover et al., 2014). This novel BoNT type was claimed to be not neutralizing with already known anti-BoNT sera justifying its assignment to a novel type (Barash and Arnon, 2014). However, BoNT/H can be neutralized by anti-BoNT/A antibodies albeit to a 16-fold higher antibody concentration than that required for BoNT/A neutralization (Pellett et al., 2016). More recently, genome analysis allowed to describe novel BoNT sequences in clostridial and non-clostridial species. Thereby, BoNT/X was identified in C. botulinum type B strain 111 that also produces BoNT/B2. BoNT/X shares a low level of sequence identity with the other BoNT types and it is not recognized by the antibodies against the previous BoNT types (Zhang et al., 2017b). BoNT related sequences have been also identified in non-clostridial species such as Weisella oryzae (BoNT/Wo or BoNT/I) from fermented rice (Zornetta et al., 2016), an Enterococcus faecalis strain (BoNT/J, or BoNT/En, or eBoNT/J) isolated from a cow (Brunt et al., 2018; Zhang et al., 2018), and Chryseobacterium piperi (Cp1) from sediment (Mansfield et al., 2019; Wentz et al., 2017). More recently, the first BoNT specific of an invertebrate species has been characterized. A Paraclostridium bifermentans subsp Malaysia strain has been found to produce a novel BoNT called paraclostridial mosquitocidal protein1 (PMP1) which specifically attacks Anopheles mosquitos (Contreras et al., 2019).

Each BoNT toxinotype shows a genetic diversity based on amino acid sequence variations. Therefore, BoNT types are divided into subtypes that were initially defined as displating at least 2.6 amino acid sequence variation (Smith et al., 2005). However, certain BoNT subtypes such as from types $B$ and $E$, show only $0.9-2.1 \%$ amino acid sequence difference, but they were assigned to distinct subtype according to the phylogenetic clade analysis. Among more than 500 BoNT sequences, 41 subtypes have been identified (Peck et al., 2017).

All BoNTs share a common structure. They are synthesized as a precursor protein (about $150 \mathrm{kDa}$ ), which is inactive or weakly active. The precursor which does not contain signal peptide, is released from the bacteria by a yet unknown mechanism. The precursor is proteolytically activated in the extra-bacterial medium either by Clostridium proteases or by exogenous proteases such as digestive proteases in the intestinal content. Hence, the active neurotoxin consists of a light chain $(\mathrm{L}$, about $50 \mathrm{kDa})$ and a heavy chain $(\mathrm{H}$, about $100 \mathrm{kDa})$, which remain linked by a disulfide bridge. The structure of BoNTs shows three distinct domains: L-chain containing $\alpha$-helices and $\beta$-strands and including the catalytic zinc binding 
protease motif (His-Glu-X-X-His), the N-terminal part of the H-chain forming two unusually long and twisted $\alpha$-helices, and the C-terminal part of the $\mathrm{H}$-chain $\left(\mathrm{H}_{\mathrm{C}}\right)$ consisting of two distinct subdomains $\left(\mathrm{H}_{\mathrm{CN}}\right.$ and $\left.\mathrm{H}_{\mathrm{CC}}\right)$ involved in the recognition of the receptor. While the three domains are arranged in a linear manner in BoNT/A and BoNT/B, both the catalytic domain and the binding domain are on the same side of the translocation domain in BoNT/E. This domain organization in BoNT/E might facilitate a rapid translocation process (Breidenbach and Brunger, 2005; Emsley et al., 2000; Fotinou et al., 2001; Fu et al., 2006; Kumaran et al., 2009; Lacy and Stevens, 1999; Lacy et al., 1998; Stenmark et al., 2008; Swaminathan, 2011; Swaminathan and Eswaramoorthy, 2000; Umland et al., 1997).

The overall sequence identity at the amino acid level between BoNTs ranges from 34 to $97 \%$. Several domains are highly conserved which account for the common mode of action of these toxins including the central domains of $\mathrm{L}$ chains containing the catalytic site, and the Nterminal half of the $\mathrm{H}$-chains that is involved in the translocation of the L-chain into the cytosol. Thus, a similar mechanism of internalization of the intracellular active domain into target cells is shared by all the clostridial neurotoxins including BoNTs and tetanus neurotoxin (TeNT) that is structurally and functionally related to BoNTs (Masuyer et al., 2017; Rossetto et al., 2013). In contrast, the C-terminal half of $\mathrm{H}$-chain, mainly the $\mathrm{H}_{\mathrm{CC}}$ subdomains, is the most divergent (Peck et al., 2017; Popoff and Marvaud, 1999; Poulain et al., 2008). This accounts for the different receptors recognized by the clostridial neurotoxins (see below).

\section{Botulinum neurotoxin interaction with target cells, BoNT receptors}

It was initially found in 1923 by Dickson and Shevky that the neurological effects of BoNTs result from the interruption of neurotransmitter release between nerve endings and muscle without damaging the anatomical structure of nerve and muscle cells (Dickson and Shevky, 1923). Later, BoNT/A was shown to specifically inhibit the release of acetylcholine from peripheral nerves and to specifically bind to the membrane of unmyelinated motorneuron endings (rev in (Dolly et al., 1984). TeNT was first characterized to bind to brain gangliosides that are mainly localized on the outer leaflet of neuronal cell membranes (Van Heyningen, 1961). BoNT binding to membrane lipids was then investigated. Trisialogangliosides were found to be effective BoNT antagonists (Simpson and Rapport, 1971), and then BoNT binding to individual ganglioside was demonstrated (rev in (Poulain et al., 2008; Rummel, 2017; Simpson, 1981) (Table 1). In addition to the structural characterization of the ganglioside binding sites on BoNTs and TeNT (rev in (Rummel, 2017), the role of 
gangliosides as receptors of BoNTs and TeNT is supported by investigations in complex ganglioside knockout mice which show an about 100 fold decreased sensitivity to clostridial toxins (Bullens et al., 2002; Kitamura et al., 1999; Rummel et al., 2007). However, gangliosides were supposed not to be the only BoNT receptors because notably the low BoNT binding affinity to gangliosides, as well as because the fact that gangliosides are localized in membranes of non-neuronal cells insensitive to BoNTs, and that BoNTs bind to trypsinand/or pronase-sensitive structures. Therefore, it was hypothesized that BoNTs recognize a dual receptor including gangliosides and a specific membrane protein (Montecucco, 1986). Later, synaptic vesicle proteins were identified as BoNT receptors. Synaptotagmin (Syt) a synaptic vesicle membrane protein involved in $\mathrm{Ca}^{++}$sensing and that triggers synaptic vesicle fusion with the presynaptic membrane, has been first characterized as the protein receptor of BoNT/B (Nishiki et al., 1994). It was further defined that BoNT/B binds with high affinity to the intraluminal domain of the Syt isoform II (Syt-II) (Nishiki et al., 1996). BoNT/G also recognizes Syt-I and Syt-II as protein receptors (Rummel et al., 2004a), as well as BoNT/DC that preferentially interacts with Syt-II (Peng et al., 2012). Due to single amino-acid change in human and chimpanzee Syt-II, BoNT/B, BoNT/DC and BoNT/G have a reduced affinity for human Syt-II as compared as that of rodent (Peng et al., 2012). Engineering of BoNT/B $\mathrm{H}_{\mathrm{C}}$ confers high affinity of modified BoNT/B human Syt-II (Tao et al., 2017), opening new therapeutic perspectives.

Then, the synaptic vesicle protein 2 (SV2) that consists in three isoforms $\mathrm{A}, \mathrm{B}$, and $\mathrm{C}$, was found to be the protein receptor of BoNT/A, BoNT/E, BoNT/D, and BoNT/F (Dong et al., 2008; Dong et al., 2006; Mahrhold et al., 2006; Peng et al., 2011; Rummel et al., 2009). BoNT binding has been localized on the intravesicular domain of SV2 (luminal domain 4, LD4). N-glycosylation of SV2 enhances BoNT/A binding to SV2, notably SV2C, and BoNT/E requires glycosylated SV2A and SV2B as functional receptors (Dong et al., 2008; Yao et al., 2016). In sharp contrast to the BoNT/B-Syt-II receptor interaction that is greatly increased by presence of poly-sialo-gangliosides, gangliosides have no synergistic effect on BoNT/A binding to SV2C (Desplantes et al., 2017; Weisemann et al., 2016). The protein receptor of BoNT/C yet remains to be defined (discussed in (Rummel, 2017)).

BoNTs interact with their membrane receptors via the Hc domain. A conserved ganglioside binding site containing the motif SXWY...G is present in $\mathrm{H}_{\mathrm{CC}}$ of BoNT/A, BoNT/B, BoNT/E, BoNT/F, and BoNT/G. The ganglioside binding site is not conserved in BoNT/C, D and DC. Hydrophobic residues located in a long loop of $\mathrm{H}_{\mathrm{CC}}$ (ganglioside binding loop) of BoNT/C, D and DC are involved in the ganglioside binding (rev in (Rummel, 2017) 
(Table 1). A second ganglioside binding site has been identified in BoNT/C. A sialic acid coordinating pocket (Sia-1) distinct of the WY-loop is located on the tip of the $\mathrm{H}_{\mathrm{CC}}$ domain of BoNT/C (Karalewitz et al., 2012; Strotmeier et al., 2011). A third structure $\left(\mathrm{H}_{\mathrm{C}}\right.$-loop) facilitating the insertion into the membrane has been recently recognized in BoNT/B, DC, and $\mathrm{G}$ that interacts with synaptotagmin as protein receptor (Stern et al., 2018; Zhang et al., 2017a). This hydrophobic loop is located in the $\mathrm{H}_{\mathrm{CC}}$ domain of BoNT/B, DC, and G between the ganglioside binding site and the protein receptor site. The $\mathrm{H}_{\mathrm{C}}$ loop is not conserved in BoNT/A, B and E (Stern et al., 2018; Zhang et al., 2017a). Co-crystallization of BoNT fragments and protein receptor allowed the characterization of the protein receptor binding sites. Homologous synaptotagmin binding sites are localized on the tip of $\mathrm{H}_{\mathrm{CC}}$ of $\mathrm{BoNT} / \mathrm{B}$, DC, and G (Jin et al., 2006; Rummel et al., 2007). The interaction of BoNT/A and BoNT/E with SV2 occurs via a distinct site than that involved in the recognition of synaptotagmin by BoNT/B. The SV2 binding site is localized in the interface between $\mathrm{H}_{\mathrm{CN}}$ and $\mathrm{H}_{\mathrm{CC}}$ in BoNT/A and BoNT/E (Benoit et al., 2014; Mahrhold et al., 2013; Strotmeier et al., 2014).

It is noteworthy that BoNT receptors (Syt, SV2) are members of a super synaptic vesicle protein complex including synaptophysin, VAMP, and subunits of the vacuolar type ATPase (v-ATPase) that is essential for vesicle acidification and subsequent translocation of BoNT (Baldwin and Barbieri, 2009). Thus, $\mathrm{H}_{\mathrm{C}}$ of all BoNT types likely recognize at the surface of nerve endings a similar 'molecular landscape', which consists of the luminal domains of the complexed synaptic vesicle proteins, physically distant each-others by $\sim 1$ or a few $\mathrm{nm}$. In this 'molecular landscape', they recognize a dual motive including a peptide + sugar residues. Depending on the BoNT type, the dual receptor is either a glucosylatedpeptide (as N-glucosylated SV2 for BoNT/A or BoNT/E) or a peptide co-localized with polysialo-gangliososides (as Syt and a poly-sialo-ganglioside).

\section{Distribution of gangliosides}

Gangliosides are glycosphingolipids with one or more sialic acid molecules (one sialic acid molecule GM, two GD, three GT, four GQ) linked on the sugar chain. Ganglioside with no sialic acid on the first galactose residue are termed "O series", those with one sialic acid "a series", and those with two sialic acid are "b series". Gangliosides are not synthetized by all animals. Except the echinoidea (i.e. the sea urchins) that produce specific types of gangliosides, invertebrates do not synthetize gangliosides (Kolter, 2012). Albeit gangliosides are present in all tissues of vertebrates, they are markedly more abundant on the neuronal cell surface (Schnaar, 2016). An important function of gangliosides on nerve cells is to mediate 
the binding of the myelin-associated glycoprotein (MAG). Thereby, gangliosides, notably GD1a and GT1b, are involved in optimal myelin formation, axon-myelin interactions, peripheral and central axon stability (Lopez and Baez, 2018; Schnaar et al., 2014). Moreover, gangliosides play critical role in the organization of ion channels at the nodes of Ranvier on myelinated fibers (Lopez and Baez, 2018).

Gangliosides are predominantly in the outer leaflet of plasma membrane. In the adult human brain, four gangliosides (GM1, GD1a, GD1b, and GT1b) constitute 97\% of the total gangliosides (Schnaar et al., 2014). The same gangliosides dominate in brain of mammals and birds. In the adult mouse brain, GM1 is mainly expressed in white matter, whereas GD1b is abundant in both white and gray matter. GD1a and GT1b are predominantly distributed in gray matter, but they are also found in some white matter areas (Vajn et al., 2013). GD1a is also present in other tissues, but GD1b and GT1b are essentially expressed in the central nervous system (CNS) (Iwamori et al., 1984).

The gangliosides GM1, GD1a, GD1b, and GT1b are also expressed in the peripheral nervous system. However, motor and sensory fibers show some differences in the content of certain gangliosides as tested with specific monoclonal antibodies. Thereby, GD1a is more abundant in motor fibers than in sensitive fibers (Gong et al., 2002). Since GD1a is one of the preferred ganglioside receptor of BoNTs (Table 1), the higher distribution of GD1a on motor fibers supports that BoNTs preferentially target the motorneurons and impair the motricity.

In contrast to the other BoNT types, BoNT/DC recognizes only sialic acids on glycosylated proteins, in the absence of all gangliosides (Zhang et al., 2017a). The neuronal selectivity of BoNT/DC is ensured by combining the recognition of sialic acids and membrane lipids through the hydrophobic loop as well as by interacting with Syt (Zhang et al., 2017a).

The intestinal mucosa is the tissue that contains the lowest level of gangliosides (400 to 700 fold less than in the brain) (Schnaar, 2019). The main ganglioside of the intestinal cells is GM1, that is the receptor of cholera toxin and Escherichia coli heat-labile enterotoxin LT-I. The variants LT-II recognize GM1, GD1a, GD1b, GT1b (Holmgren et al., 1975; Schnaar, 2019). However, it is not known whether LT-II uses GD1a, GD1b, GT1b as receptor on the intestinal cells since these gangliosides are not present or only at low level on the intestinal mucosa.

The higher abundance of gangliosides in nerve tissues versus the other tissues associated to the high prevalence of the gangliosides used as BoNT receptors (GD1a, GD1b, 
GT1b) (Iwamori et al., 1984; Schnaar, 2019; Svennerholm et al., 1994) contributes to the neuronal selectivity of BoNTs.

\section{Distribution of synaptic vesicle protein 2}

Synaptic vesicle protein2 (SV2) is a transmembrane glycoprotein that is present in secretory vesicles of all neurons and endocrine cells, but not exocrine cells (Buckley and Kelly, 1985). SV2 is present in synaptic vesicles membrane of all peripheral and central neurons, in secretory granules of endocrine cells, but not exocrine cells (Bartholome et al., 2017; Buckley and Kelly, 1985). Three SV2 isoforms (SV2A, SV2B, and SV2C) have been identified based on gene cloning. Immunocytochemistry and in situ hybridization have revealed that SV2A and SV2B are widely distributed in all brain areas. However, SV2B is not found in all synapses and it is preferentially observed in brain subregions of the hippocampal formation (Janz and Südhof, 1999). In contrast to SV2A and SV2B, SV2C shows a more restricted distribution. SV2C is mainly localized in the basal ganglia system (pallidum, substantia nigra) that coordinates the motor control functions, the midbrain, the brainstem and the olfactory bulb and is undetectable in the cerebral cortex, the hippocampus, and at low levels in the cerebellar cortex (Janz and Südhof, 1999). SV2C expression is not specific of particular neurotransmitter-producing neuronal cells, since it can be observed in GABAergic, cholinergic, dopaminergic neurons. However, in the striatum SV2C is mainly expressed in cholinergic interneurons. Overall, SV2A is associated with synaptic vesicles containing glutamate or GABA (gamma-amino-butyric-acid), SV2B with glutamate containing vesicles and SV2C with vesicles containing acetylcholine, dopamine, GABA (Bartholome et al., 2017; Dardou et al., 2011; Dunn et al., 2019).

In the peripheral nervous system, SV2C as well as SV2A and SV2B are present at the motor nerve terminals (Dong et al., 2006). Since SV2C is the preferred receptor of BoNT/A and that BoNT/A is mainly active at the neuromuscular junctions, SV2C seems to have a major role in mediating BoNT binding and ensuing internalization at these nerve terminals (Dong et al., 2006; Mahrhold et al., 2006). SV2A protein is expressed in the human peripheral nervous system including sensory system (dorsal root ganglion neurons and their axon/terminals), autonomic nerve system (innervation of sweat glands) and intestinal nervous system (Yiangou et al., 2011). SV2 proteins have been detected in almost all the cholinergic parasympathetic fibers and in only half of the sensory fibers innervating the human bladder (Coelho et al., 2010). This supports why BoNT/A has a major inhibitory effect on the motricity of the bladder by impairment of the neurotransmitter release from the 
parasympathetic fibers. The effect of BoNT/A in treating acute pain might also results from the inhibition of neurotransmitter release involved in pain signaling (CGRP, substance P) and in decreased expression of nociceptors (TRPV1, P2X3, CGRP receptor) (see paragraph 8-4 and (Coelho et al., 2010). Altogether, these observations explain why manufactured BoNT/A can be used with success in urology or to decrease gland secretion (e.g. hyperhidrosis, drooling).

It is noteworthy that the BoNTs interacting with SV2 recognize the glycosylated isoforms of this protein. Thereby, BoNT/A interacts with both the peptide moiety and an Nlinked glycan on SV2. BoNT/A binding with high affinity to neuronal cell surface includes the synergistic recognition of both glycosylated SV2 (glycan and peptide moieties) and gangliosides (Yao et al., 2016). The combined interaction with both SV2 and gangliosides ensures the neuronal selectivity of these neurotoxins and thus greatly contributes to the extreme potency of these toxins. The double receptor likely contributes to the preferential targeting of certain neuron types by BoNT (such as cholinergic neurons, see below) and to the membrane localization close to the exocytosis machinery. Indeed, BoNT/A and BoNT/B have been found to bind only to neuron terminal membrane and not to all along the neuronal membrane (Black and Dolly, 1987; Dolly et al., 1984).

\section{Distribution of synaptotagmin}

Synaptotagmins (Syt) are characterized by a N-terminal transmembrane region with a very small vesicle lumen portion and a long cytoplasmic domain containing two ' $\mathrm{C} 2$ domains' which affinity for lipids is $\mathrm{Ca}^{++}$-dependent. Syt is the main $\mathrm{Ca}^{++}$sensor that triggers the fusion of synaptic vesicles with the presynaptic plasma membrane upon a rise in intracellular $\mathrm{Ca}^{++}$(Chapman, 2008; Jahn and Fasshauer, 2012). Among the 17 Syt isoforms that have been described so far, Syt-I and Syt-II are the main players of synaptic vesicle exocytosis (Ahnert-Hilger et al., 2013). Other Syt isoforms are involved in secretory granule fusion (Jahn and Fasshauer, 2012).

Syt-I is widely distributed in all types of brain neurons, in terminals of autonomic and sensory neurons, and in subpopulation of neuromuscular junctions (rev in (Ahnert-Hilger et al., 2013). In contrast, Syt-II is expressed in restricted neuron populations of the forebrain and in the majority of both excitatory and inhibitory neurons and cholinergic motor nerves in the brain stem and spinal cord. Notably, Syt-II is strongly expressed in neuromuscular junctions (Pang et al., 2006). 
The high affinity receptor of BoNT/B consists in the interwined association of Syt and GT1b (Flores et al., 2019). Not only the distribution of Syt, but also the appropriate conformation of both Syt and gangliosides seem determinant for the selective BoNT binding to neuronal cells, and probably to specific membrane areas of neuronal cells.

\section{BoNTs block the release of various neurotransmitters from neuronal cells}

Studies performed with neuronal cell lines and primary neuronal cell cultures or synaptosome preparations have revealed that BoNTs not only block cholinergic transmission but also inhibit the release of a large variety of neurotransmitters their exocytosis of which is mediated by SNARE-dependent mechanisms (rev in (Popoff and Poulain, 2010).

Most of the inhibitory effects of the BoNTs have been investigated with BoNT/A. Representative neurotransmitters the release of which is blocked by BoNT are shown in Table 2. However, BoNTs affect not all types of neurons. For examples, BoNT/A does not prevent the release of neuropeptide $\mathrm{Y}$ from vasoconstrictor afferent neurons in guinea pig vena cava and uterine (Morris et al., 2002), vasointestinal peptide (VIP) and calcitonin gene related peptide (CGRP) from periglandular innervation of sweat glands (Swartling et al., 2004).

Comparison of the efficiency of BoNTs in different neuronal cell types in culture by monitoring the cleavage of the intracellular target, SNAP25 or VAMP, showed that BoNT/A1, BoNT/B1, BoNT/C, and BoNT/E are more potent in motor-neurons than in GABAergic, DOPAergic, and glutamatergic neurons (Pellett et al., 2019). Thereby, motorneurons are more sensitive than the other neuronal cell types to BoNTs. This greater sensitivity of motor-neurons can result from multiple factors (expression of the intracellular target, expression of the protein and ganglioside receptors, glucosylation of cell surface proteins, cell maturity and differentiation, and/or synaptic activity) (Pellett et al., 2019).

Moreover, BoNTs can block the exocytosis in non-neuronal cells, but at high concentration since these cells do not express specific BoNT receptors or at very low level. Thereby, BoNT/A prevents the release of catecholamines from chromaffin cells albeit using high toxin concentration (Ahnert-Hilger et al., 1989; Penner et al., 1986), ATP and glutamate from glial cells (Abdipranoto et al., 2003; Araque et al., 2000), insulin from pancreatic betacells (Regazzi et al., 1996), and NAD from human bladder detrusor muscle cells (Breen et al., 2006; Smyth et al., 2006). BoNT/D was reported to block the secretion of the tumor necrosis factor (TNF) from monocytes (Imamura et al., 1989). Treatment of non-neuronal cells like astrocytes with $\mathrm{BoNT} / \mathrm{B}$ or $\mathrm{BoNT} / \mathrm{F}$ at high concentration resulted in the cleavage of the 
substrate VAMP2. BoNTs were identified in endocytic compartments suggesting that the toxins exploit a fluid-phase endocytosis to enter non-neuronal cells (Verderio et al., 1999).

Some signaling molecules are released by two different types of mechanisms, one of the two being SNARE-dependent. This is the case of the purine ATP, which when cytosolic can be released through hemichannels or pannexons (e.g. by glial cells) in a BoNT-insensitive manner (Abudara et al., 2018), whereas vesicular exocytosis of ATP which occurs when this purine is co-stored with a neurotransmitter, as acetylcholine, is blocked by BoNTs (Lawrence et al., 2010; Unsworth and Johnson, 1990). Depending on the importance of SNAREdependent release in these cells, BoNT may prove efficient or not. For instance, BoNT/A blocks evoked release of both $\beta$-NAD, ATP and Nor-Adrenalin from human bladder detrusor preparation, however $20 \%$ of $\beta$-NAD release remains resistant (Breen et al., 2006; Smyth et al., 2006).

Thereby, based on cultured neuronal cells, BoNTs are able to block the release of any type of neurotransmitter when its secretion is SNARE-dependent (Table 2).

\section{Neuronal cell types targeted by BoNTs}

\section{8-1 BoNTs and motor-neurons}

The neuromuscular junction between motor-neurons and skeletal muscles is considered as the main target of BoNTs and their inhibitory effects at this site are well documented (rev in (Habermann and Dreyer, 1986; Molgo et al., 1990; Montal, 2010; Poulain et al., 2008; Rossetto et al., 2015; Simpson, 2013; Tighe and Schiavo, 2012; Wellhöner, 1992). Indeed, BoNT/A and BoNT/B bind with high affinity to presynaptic membrane of cholinergic nerve terminals forming the synapse between the $\alpha$-motor-neurons and striated muscle fibers (Black and Dolly, 1986a, b; Dolly et al., 1984). In contrast, no specific binding of BoNT/A to noradrenergic terminals has been observed in mouse hemidiaphragm preparations (Dolly et al., 1984). The activity of BoNT/A and BoNT/B is dependent of their uptake by motor nerve terminals (Black and Dolly, 1986a, b). This internalization is mediated mainly via synaptic vesicle recycling, as indicated by the presence of neurotoxin molecules into endocytic vesicles decorated by synaptic vesicle marker SV2 (Colasante et al., 2013). Since some intracellular cargos containing BoNT undergo retrograde ascent toward the CNS through $\alpha$ motorneuron (Surana et al., 2018), it is likely that endocytotic vesicles other than recycling vesicle participate to BoNT internalization. Inhibition of evoked acetylcholine release by nerve terminals of $\alpha$-motorneurons results in subsequent flaccid paralysis that is the main 
characteristic symptom of botulism (rev in (Poulain et al., 2008). Electrophysiological studies have revealed that there is a decrease in the number of acetylcholine quanta released in response to arrival of action potentials to nerve endings. Depending on the used BoNT toxinotype, evoked release remains synchronous (e.g. as after BoNT/A) or becomes partially asynchronous (as after BoNT/B). Moreover, spontaneous quantal release of acetylcholine is also decreased (Humeau et al., 2000; Poulain et al., 1995; Poulain et al., 2008). Weakening of muscle strength by BoNT results also greatly from muscle fiber atrophy (Scott, 1981), which is an indirect consequence of motor-nerve terminals silencing.

Depending on the mammalian species, the ability of BoNTs to induce paralysis varies considerably. Presence of point mutation in human Syt-II considerably decreases affinity of BoNT/B, but preserves its affinity for Syt-I (Peng et al., 2012). Although, Syt-II is more abundant than Syt-I on motor nerve terminals, BoNT/B binding to Syt-I is sufficient to mediate internalization of BoNT/B insde human motor nerve endings, albeit in a reduced manner. Thus, whereas BoNTA and BoNT/B are equipotent for inducing muscle relaxation in rodents, approximately 40 times more BoNT/B than BoNT/A is needed in humans (Sloop et al., 1997). When BoNT/B is used in human for therapeutic purpose, very high amounts of this toxin need to be injected to induce muscle relaxation to the price of undesired side effects. Indeed, hematogenous dissemination allows sufficient amount of BoNT/B to act on nerve endings of the autonomic nervous system (which are rich in Syt-I). Thus BoNT/B cause more frequent dysautonomia (see below) adverse effects, than when BoNT/A is used (Dressler and Benecke, 2007; Sloop et al., 1997). The 40-fold lower BoNT/B affinity for human Syt compared to the high affinity for Syt from rodents is due to a single amino acid change in Syt luminal domain, leucine in human Syt versus phenylalanine in rodent Syt (Peng et al., 2012; Strotmeier et al., 2012). An engineered BoNT/B retaining full binding affinity and activity in human motor-neurons has been constructed. This modified BoNT/B is a candidate for an efficient therapeutic drug on the skeletal muscles (Elliott et al., 2019).

Since BoNT/D looks lacking the synergistic ganglioside binding site (Zhang et al., 2010), it has virtually no effect on neuromuscular transmission in human muscles (Eleopra et al., 2013) and indeed it is an extremely rare cause of naturally acquired human botulism. Gangliosides and SV2 are required for BoNT/D binding and entry into rat and mouse neurons and for neurotoxicity in mouse hemidiaphragm (Peng et al., 2011; Strotmeier et al., 2010). BoNT/D retains two carbohydrate binding sites in the Hc domain, which are distinct from those characterized on BoNT/A, B, E and G, and recognizes SV2 via a different mechanism from BoNT/A and E (Peng et al., 2011; Strotmeier et al., 2010). The apparent insensitivity of 
human neurons to BoNT/D seems not to be related to SV2 mutation. This might result from an appropriate conformation of both gangliosides and SV2 on rodent neuron membrane distinct from that on human neurons.

BoNT/A affects both extrafusal ( $\alpha$-motor-neurons) and intrafusal ( $\gamma$-motor-neurons) cholinergic nerve terminals (Filippi et al., 1993; Rosales et al., 1996). Indeed, BoNT/A can inhibit acetylcholine release by intrafusal $\gamma$-motor nerve endings (i.e. the nerve terminals from $\gamma$-motor-neurons innervating contractile fibers in the muscle spindle) (Filippi et al., 1993; Rosales et al., 1996). $\gamma$-motor-neurons nerve endings are inside the spindle capsule, which acts as an imperfect diffusional barrier, possibly decreasing exposure of intrafusal nerve endings to BoNT. Hence, after muscle treatment with BoNT, the $\alpha-\gamma$-motor-neuron coupling as well as muscle proprioception are modified (Rosales and Dressler, 2010). This adds to change in the proprioceptive information from tendon and joint receptors induced by muscle weakening. Therefore, somato-sensory and motor command computations in CNS are strongly modified, accounting for at least some of the so-called central effects of BoNTs.

Numerous data indicate that at the motor nerve ending BoNT blocks not only secretion of acetylcholine but also that of other compounds (Table 2), the release of which is mediated by the SNARE-machinery, as ATP (Lawrence et al., 2010). Motor-nerve endings contains large dense core granules containing peptides as the Calcitonin Related Gene Peptide (CGRP) (Russell et al., 2014). Although inhibition of CGRP release by motor-nerve endings has not been proven as it is with other neurons, accumulation of CGRP containing dense core vesicles after BoNT/A suggests that CGRP exocytosis is prevented (Meunier et al., 1996). This might be also the case for a number of other peptides as Agrin. Importantly, the decrease in release of acetylcholine, ATP, and possibly Agrin is detected by muscle fibers that react by initiating atrophy program (Cisterna et al., 2014). Muscle fiber atrophy greatly contributes to reduce muscle strength (Scott, 1981). Decrease in CGRP release is likely responsible for acetylcholine receptor redistribution (rev (Poulain et al., 2008).

Thereby, BoNT binding to terminal ends of motor-neurons and inhibition of acetylcholine release are the characteristic features of these toxins.

\section{8-2 BoNTs and the autonomic nervous system}

In addition to motor-neurons, BoNTs enter various peripheral neurons. BoNT/A can block cholinergic pre- and post-ganglionic nerve terminals of the parasympathetic and sympathetic autonomic nervous system thus affecting smooth muscle and secretion and 
leading to autonomic dysfunction (rev in (Rossetto, 2018). The parasympathetic nervous system consists of a first peripheral preganglionic cholinergic neuron connected by myelinated axon to a second post-ganglionic cholinergic neuron innervating the effector organ. The first peripheral neuron of the sympathetic nervous system is also cholinergic and its axon myelinated, whereas the second post-ganglionic neuron, located in the paravertebral truncus, which reaches the effector organs is adrenergic (Dressler, 2013). Note, however, that the sympathetic post-ganglionic neuron innervating the sweat glands might be adrenergic or cholinergic. Symptoms resulting from the autonomic nervous system dysfunction are observed in naturally acquired botulism such as inhibition of secretions (dry mouth, dry throat, xerophtalmia, urinary retention and intestinal hypomotility as constipation (Sobel, 2005). Thereby, BoNT, especially BoNT/A, is used for the treatment of hypersecretions such as hyperhidrosis, hypersalivation, and hyperlacrimation (Dressler, 2013; Naumann et al., 2013). BoNT effects likely result from toxin activity on peripheral post-ganglionic nerve terminals. Indeed, the pre-ganglionic neuronal cell bodies are located in the CNS and are protected against BoNT by the blood-brain barrier. Myelination of pre-ganglionic axons prevents BoNT binding (Dolly et al., 1984). Moreover, the nerve terminals and cell bodies of the post-ganglionic neurons are located inside the autonomic ganglia which are protected from circulating large molecules by a blood barrier that is more permeable than the bloodbrain barrier (Chau and Lu, 1996; Kiernan, 1996).

Heart is innervated by autonomic nervous system (parasympathetic -cholinergic- and sympathetic -catecholaminergic-). Despite heart cholinergic innervation plays important role in cardiac regulation, BoNT moderately affects heart function. However, injection of botulinum toxin into epicardial fat pads can be used to suppress atrial fibrillation (Romanov et al., 2019).

A particular effect of BoNT on smooth muscle innervation is on the bladder. Urinary retention is observed in many cases of botulism (Carpenter, 1967; Loiseau et al., 2010; Merz et al., 2003; Sautter et al., 2001), and BoNT, especially BoNT/A, is used in several urological applications notably to diminish detrusor overactivity (Hanchanale et al., 2010). The bladder smooth muscle detrusor, is innervated by cholinergic/cholinergic parasympathetic and cholinergic/adrenergic sympathetic nerve fibers, and the urothelium/sub-urothelium receives sensory afferent nerve terminals (Fig. 1) (Chancellor and Yoshimura, 2004). SV2 and SNAP25, that are the protein receptor and the intracellular substrate of BoNT/A respectively, are expressed by the nerve fibers of human bladder sub-urothelium and muscular layers. However, SV2 is more abundant in cholinergic parasympathetic fibers than in sympathetic 
and sensory fibers (Coelho et al., 2010). BoNT treatment is indicated in overactive bladder or neurogenic detrusor overactivity. BoNT/A reduces the contraction of the detrusor by inhibiting the release of acetylcholine and its co-transmitter ATP as well as by acting on the sensory terminals in the urothelium/suburothelium (Apostolidis et al., 2006). This inhibition is correlated with cleavage of SNAP25 in cholinergic parasympathetic fibers and in half of the sympathetic and sensory neurons (Coelho et al., 2012a, b). It is noteworthy that cleaved SNAP25 is detected a very long time (up to 11 months) after botulinum toxin injection in the human detrusor. This might account with the absence of nerve sprouting for the long duration of clinical effect of BoNT/A in the urological indications (Schulte-Baukloh et al., 2007).

In addition, BoNT/A prevents the release of neurotransmitters in urothelium by afferent sensory nerves such as ATP, substance P, and CGRP (Apostolidis et al., 2006). In animal model, intrathecal administration of BoNT/A that restricts the toxin activity on sensory fibers, reduces the expression of CGRP associated to SNAP25 cleavage in sensory dorsal horn neurons as well as neuronal change including up-regulation of ATF3 (activating transcription factor 3 involved in regenerating neurons) leading to a strong analgesic effect on bladder pain and bladder hyperactivity (Coelho et al., 2016; Coelho et al., 2014). The inhibitory activity of BoNT/A on sensory signaling likely contributes to the relief of sensory symptoms in patients with bladder dysfunction such as neurogenic detrusor overactivity (Chancellor et al., 2008; Coelho et al., 2014; Ikeda et al., 2012; Rapp et al., 2006).

An additional effect of BoNT/A administration in bladder consists in reducing the neuronal expression of the ATP receptor $\mathrm{P}_{2} \mathrm{X}_{3}$ and TRPV1 (transient receptor potential channel, vanilloid family member) receptor most probably by blockade of their SNAREdependent trafficking (Apostolidis et al., 2005; Lawrence et al., 2010). The P2 $\mathrm{X}_{3}$ and TRPV1 receptors are expressed in sensory nerve fibers and have a main role in nociception. The reduction of nociceptive receptors in subu-rothelial sensory nerves contributes to the beneficial effect of BoNT/A treatment on the hyperalgesia relief in urology (Chancellor et al., 2008).

BoNTs are able to target neurons of the autonomic nervous system including neurons innervating smooth muscles and glands as well as sensory neurons. BoNTs block the release of neurotransmitter in these neurons and also the expression of nociceptors in sensory neurons which is SNARE-dependent. BoNT trafficking to the autonomic nervous system in naturally acquired botulism remains to be better determined.

\section{8-3 BoNTs and the central nervous system}


As already mentioned, BoNTs affect other neuronal cell types than cholinergic neurons and can target neuronal cells from the central nervous system (Table 2). Using brain synaptosomes, BoNT/A1 and BoNT/E enter equally GABAergic inhibitory neurons and excitatory glutamate terminal nerve endings that contain SV2A and SV2C by synaptic vesicle recycling (Verderio et al., 2007). However, both BoNT/A and BoNT/E inhibit more efficiently the release of glutamate than that of GABA from hippocampal neurons. It was hypothesized that the lower sensitivity of inhibitory neurons to the BoNTs correlates with a lower level of the intracellular target SNAP25 or expression of a distinct SNAP25 isoform. Indeed, overexpression of SNAP25 in GABAergic neurons confer them a higher sensitivity to BoNTs (Verderio et al., 2004). The differential effect of BoNT/A and BoNT/E on excitatory versus inhibitory neurons offers the possibility of using these toxins in the therapy of some CNS diseases.

BoNT/A2 at extremely low concentration was also found to inhibit the spontaneous mono-quantal (miniature) and evoked release by glutamatergic excitatory and glycine/GABA inhibitory neurons in the rat spinal cord. The inhibitory effect was more pronounced in evoked rather than in spontaneous mono-quantal release. BoNT/A2 was more efficient in blocking inhibitory than excitatory neurons (Akaike et al., 2010). BoNT/B and BoNT/F that cleave VAMP instead of SNAP25 as BoNT/A and BoNT/E are also able to enter central hippocampal neurons and astrocytes (Verderio et al., 1999).

BoNT/A and BoNT/E, especially at high doses, are able to undergo the retrograde axonal transport and to enter the CNS, but much less efficiently than TeNT (Antonucci et al., 2008; Restani et al., 2012a). Using the in vivo model of rat visual pathway, it was demonstrated that BoNT/A induces neurotransmission impairment in at least two synapses away from the injection site upon retroaxonal transport preferentially via cholinergic neurons (Restani et al., 2012b). Some physiological changes in humans following therapeutic intramuscular injection of BoNT/A such as reorganization of CNS circuitry suggest direct central action of the toxin (Caleo and Restani, 2018; Weise et al., 2019). The effects of BoNT on CNS neurons have been mainly investigated with cultured neurons or tissues, and the central neuron types targeted by in vivo toxin administration likely by axonal retrograde transport remain to be precisely determined.

\section{8-4 BoNTs, sensory and nociceptive neurons}

As mentioned above, BoNTs prevent the release of neurotrasmitters of sensory neurons such as CGRP, substance P using cultured neurons (Table 2). The activity of BoNTs on 
sensory neurons in vivo has been investigated on pain relief in experimental animals. For example, subcutaneous injection of BoNT/A prevents inflammatory pain in rats by reducing neurotransmitter (glutamate, substance P, CGRP) release from peripheral sensory neuron endings indicating that BoNT/A can modulate neurogenic inflammation (Aoki, 2005; Matak et al., 2014). Since unilateral BoNT/A injection is able to produce bilateral anti-nociceptive effect in intramuscular acidic saline-induced pain assay, it has been suggested that BoNT/A decreases nociception via a central effect, possibly due to retroaxonal ascent of BoNT/A molecules to the CNS that have been injected peripherally (rev in (Filipovic et al., 2012; Matak et al., 2014)). Accordingly, inhibition of retrograde transport by colchicine prevent the anti-nociceptive effect of BoNT/A (Bach-Rojecky and Lackovic, 2009). Moreover, BoNT effect has been described in the ganglions (Dorsal Root Ganglion, DRG) or nuclei containing sensory neurons whose nerve endings extend to the periphery. Indeed, peripherally injected BoNT/A decreases the release of neurotransmitters from rat trigeminal ganglion neurons (Kitamura et al., 2009). In the in vivo pain model of chronic constriction injury of sciatic nerve in mouse, peripheral injection of BoNT/A induces analgesic effects associated with massive cleavage of SNAP25 in dorsal horn of spinal cord. These observations further support a central action of BoNT/A subsequently to axonal retrograde transport (Marinelli et al., 2012). Antinociceptive effect of BoNT/A injected subcutaneously in rats is associated with cleaved SNAP25 in the trigeminal nucleus caudalis (TNC), but not in higher level nociceptive nuclei (Matak et al., 2014). The antinociceptive effect of BoNT/A is directed only against certain forms of pain such as capsaicin-induced pain. BoNT/A preferentially targets peripheral and central TRPV1 expressing neurons that are primarily glutamatergic (Matak et al., 2014). However, the precise sets of sensory neurons targeted by BoNT/A and nociceptive signaling pathways blocked by this toxin remain to be further defined. Cleavage of VAMP2, VAMP3 and to greater extent VAMP1 by BoNT/B or D results also in inhibition of CGRP and substance $\mathrm{P}$ evoked release from trigeminal ganglionic neurons (Meng et al., 2014).

In addition, local injection of BoNT decreases the expression of noci-receptors on sensory neurons contributing to the BoNT-dependent prevention of pain. Subcutaneous injection of BoNT/A in rats diminishes neuropathic pain and this effect is associated with a reduced expression of $\mathrm{P}_{2} \mathrm{X}_{3}$ receptor on DRG neurons (Xiao et al., 2011). In addition, intraarticular administration of BoNT/A reduces the expression of TRPV1 in DRG neuron as well as arthritis hyperalgesia indicating that the toxin has access to the CNS by axonal retrograde transport and target sensory neuronal signaling (Fan et al., 2017). Decrease in TRPV1 expression in trigeminal ganglion neurons has also been observed after subcutaneous 
injection in rat (Shimizu et al., 2012). Cleavage of SNAP25 by BoNT/A likely inhibits the exocytosis and translocation of TRPV1 to the membrane rendering the molecule susceptible to ubiquitination and subsequent proteasomal degradation (Shimizu et al., 2012).

Medical use of BoNT, mainly BoNT/A, shows that the toxin is effective in the treatment of various neuropathic pain syndromes including post-herpetic neuralgia, trigeminal neuralgia, and peripheral neuralgia (Park and Park, 2017; Safarpour and Jabbari, 2018). Notably, clinical studies have confirmed the efficacy of BoNT/A in the treatment of chronic migraine, but not in episodic migraine, and it is a recommended alternative to other headache preventive drugs (Ashkenazi and Blumenfeld, 2013; Ramachandran and Yaksh, 2014). This again supports the idea that peripheral administration of BoNT/A not only induces an inhibition of neurotransmission at the neuromuscular junction, but it also produces effects on peripheral and central sensory neurons (Do et al., 2018). A chimera toxin comprising the L chain and translocation domain of BoNT/A combined to the receptor binding domain of TeNT thus allowing the binding to CNS neurons and not to neuromuscular junctions was engineered. This chimera toxin retains anti-nociceptive activity without inducing muscle paralysis (Ferrari et al., 2013; Mangione et al., 2016). This raises the possibility to engineer molecules that target preferentially sensory neurons versus motor-neurons.

In addition to their main inhibitory activity on motorneurons, BoNTs also target sensory neurons, notably noniceptive neurons. This opened the way to novel applications of BoNTs such as the treatment of pain.

\section{8-5 BoNTs, intestinal barrier, and enteric nervous system}

Food borne botulism and botulism by intestinal colonization are the most prevalent forms of botulism and the passage of the intestinal barrier represents the first step of the intoxication.

Using animal experimental models, it was found that BoNT can be absorbed from different digestive segments including stomach, ileum, and colon. However, the upper small intestine was identified as the most efficient absorption site (Bonventre, 1979; Maksymowych et al., 1999; May and Whaler, 1958). BoNT complexes containing hemagglutinins (HA) can be transported through $\mathrm{M}$ cells and since HAs are able to disrupt the E-cadherin intercellular junctions between intestinal epithelial cells, BoNT can pass the intestinal barrier via the paracellular pathway. In addition, BoNT free of HAs can be transported by transcytosis through certain intestinal epithelial cells (Fujinaga and Popoff, 2018; Lee et al., 2014; Matsumura et al., 2008; Matsumura et al., 2015; Popoff and Connan, 2014; Sugawara et al., 
2010). Using fluorescent BoNT/A and BoNT/B or their corresponding receptor binding domains, it has been found that these molecules interact with intestinal epithelial cell surface, but with a much lower affinity than on neuronal cells. BoNT interaction with intestinal epithelial cells or BoNT passage through the mouse intestinal epithelium were impaired by preincubation with the gangliosides GD1b/GT1b but not GM1. This supports that the BoNT/A and BoNT/B receptors on epithelial cells mainly comprise the gangliosides GD1b/GT1b without the requirement of a protein part (Connan et al., 2016; Connan et al., 2017; Couesnon et al., 2009).

The cells of the intestinal mucosa and submucosa targeted by BoNT/A and BoNT/B were investigated by administration of fluorescent toxin into mouse ligated intestinal loops and histological analysis (Connan et al., 2016; Couesnon et al., 2012). When passed across the intestinal barrier, BoNT/A and BoNT/B stained neuronal cells and neurites, and no other cell types such as glial cells, muscle cells, or connective cells. As tested in transgenic Thy1YFP mouse where the enteric nervous system (ENS) is nicely labeled, BoNT/B colocalizes with neuronal cell bodies and neuronal cell extensions, but not all the neuronal cells are recognized by the toxin (Connan et al., 2016). This indicates that BoNT targets specific neuronal cell types in the ENS. BoNT/A and BoNT/B recognize mainly the cholinergic neurons and their extensions in the intestinal submucosa. Almost all the cholinergic neurons were co-stained with BoNT. To a lower extent, the serotonergic cells are targeted by the toxins, and only a low proportion of the other neuronal cell types are labeled by the BoNTs (Fig. 2). It is noteworthy that except cholinergic and serotonergic neuronal cells, the other neuronal cell types are underrepresented in the ENS. Cholinergic neurons have an important role in the control of the gastrointestinal motility and secretion, but serotonergic neurons are also involved in the control of gastrointestinal peristalsis (Furness et al., 2014; Gershon, 2013; Li et al., 2011). Thereby, BoNT targeting of cholinergic and serotonergic neurons, accounts for the botulism intestinal symptoms the botulism intestinal symptoms that are characterized by constipation (decrease in intestinal motility and secretion). Notably the first and predominant symptom in infant botulism is constipation (Fenicia and Anniballi, 2009; Fox et al., 2005; Rosow and Strober, 2015). It is questionable whether the BoNT activity on the noncholinergic ENS neuronal cell types contributes to the local paralysis or mediates other effects, such as toxin dissemination to other local or CNS neurons. Indeed, the ENS is highly interconnected with neurons from the CNS and BoNT has been found to undergo neuronal retrograde transport (Caleo and Restani, 2018; Restani et al., 2012a). 


\section{Concluding remarks}

BoNTs are powerful neurotoxins because they attack SNAREs, the key molecules of regulated exocytosis, and because they act on the nervous system, whose functioning is vital for metazoans. Their neuronal selectivity is not specifically related to the presence of SNAREs, which are also expressed by non-neural cells, but by the recognition of specific receptors present on the neuronal cell surface. Indeed, BoNTs interact with a double receptor (ganglioside and luminal domain of a synaptic vesicle protein) that allows them to enter cellular regions with very high exocytosis and endocytosis activity, such as nerve endings. Subsequent translocation of the catalytic L-chain into the cytosol leads to SNARE cleavage and blocks exocytosis mechanisms. This results in inhibition of the release of neurotransmitters or neuromodulators, as well as blocking the insertion of certain receptors into the membrane. Finely understanding these multiple cellular effects has implications for naturally acquired botulism and therapeutic applications of BoNTs. Although BoNTs can block the release of neurotransmitters in almost all neuronal cells as deduced from in vitro studies, symptoms of naturally acquired botulism appear to result exclusively from the inhibitory action of BoNTs on cholinergic nerve endings. Would BoNTs only affect cholinergic neurons in vivo during botulism? Answering this question is difficult because we do not know how to track the trafficking of BoNT molecules in the host at very, very low concentrations, such as those involved in naturally acquired botulism. However, the medical use of BoNTs in a growing number of indications has provided new, albeit indirect, information on the neuronal selectivity of these molecules. In particular, clinical studies following the administration of BoNT have indicated that the effects of BoNTs are not limited to cholinergic neurons alone. For example, applications of BoNT in urology and pain relief show that these toxins also affect non-cholinergic transmission. Such effects of BoNTs have no counterpart in botulism. Indeed, there have never been any reports of altered proprioception or no pain during botulism. Local concentrations of BoNT reached during therapeutic injection are likely far exceeding those observed during botulism. Do the cholinergic nerve endings that innervate the exocrine glands and muscle fibers express specific combinations of receptors that give them a better affinity for BoNTs than nerve endings of other types of neural cells? Clearly, there is a lack of mapping of the distribution of receptors to BoNTs, both for the protein part and gangliosides. Such mapping could provide an important breakthrough in the clinical development of BoNT treatment. Other factors have an impact on the type of neuron reached by BoNTs. For example, the mode of entry or administration of BoNT to the host (oral intoxication versus local injection) 
influences the access of the toxin to its target neuronal cells. However, BoNT's traffic from its injection site to the final target neurons (local diffusion, dissemination in intercellular space, retrograde axonal transport to the CNS) remains to be defined. In naturally occurring botulism, such as foodborne botulism, the entry sites of BoNT (upper or lower part of the digestive tract) and the mode of spread (blood, lymph) are still hypothetical. Does the enteric nervous system play a role in the entry of BoNT and its dissemination to other target neurons? What is the role of non-cholinergic neurons of the enteric nervous system targeted by BoNTs? Do they facilitate the entry of BoNT and its dissemination to other target neurons? A better understanding of the multiple facets of the neuronal selectivity and in vivo trafficking of BoNTs will make it possible to understand the multiple symptoms and manifestations of natural disease and to design new and effective therapeutic applications for BoNTs.

\section{Credit authorship contribution statement}

Bernard Poulain: writing - review \& editing. Emmanuel Lemichez: writing - review \& editing. Michel R Popoff: Conceptualization, Writing original draft, Writing - review \& editing.

\section{References}

Abdipranoto, A., Liu, G.J., Werry, E.L., Bennett, M.R., 2003. Mechanisms of secretion of ATP from cortical astrocytes triggered by uridine triphosphate. Neuroreport 14, 2177-2181.

Abudara, V., Retamal, M.A., Del Rio, R., Orellana, J.A., 2018. Synaptic Functions of Hemichannels and Pannexons: A Double-Edged Sword. Front Mol Neurosci. 11:435., 10.3389/fnmol.2018.00435. eCollection 02018.

Ahnert-Hilger, G., Munster-Wandowski, A., Holtje, M., 2013. Synaptic vesicle proteins: targets and routes for botulinum neurotoxins. Curr Top Microbiol Immunol 364:15977., 10.1007/1978-1003-1642-33570-33579_33578.

Ahnert-Hilger, G., Weller, U., Dauzenroth, M.E., Habermann, E., Gratzl, M., 1989. The tetanus toxin light chain inhibits exocytosis. FEBS Lett 242, 245-248.

Akaike, N., Ito, Y., Shin, M.C., Nonaka, K., Torii, Y., Harakawa, T., Ginnaga, A., Kozaki, S., Kaji, R., 2010. Effects of $A 2$ type botulinum toxin on spontaneous miniature and evoked transmitter release from the rat spinal excitatory and inhibitory synapses. Toxicon 56, 1315-1326.

Antonucci, F., Rossi, C., Gianfranceschi, L., Rossetto, O., Caleo, M., 2008. Long-distance retrograde effects of botulinum neurotoxin A. J Neurosci 28, 3689-3696.

Aoki, K.R., 2005. Review of a proposed mechanism for the antinociceptive action of botulinum toxin type A. NeuroToxicology 26, 785-793. 
Apostolidis, A., Dasgupta, P., Fowler, C.J., 2006. Proposed mechanism for the efficacy of injected botulinum toxin in the treatment of human detrusor overactivity. Eur Urol. 49, 644-650. doi: 610.1016/j.eururo.2005.1012.1010. Epub 2006 Jan 1014.

Apostolidis, A., Popat, R., Yiangou, Y., Cockayne, D., Ford, A.P., Davis, J.B., Dasgupta, P., Fowler, C.J., Anand, P., 2005. Decreased sensory receptors P2X3 and TRPV1 in suburothelial nerve fibers following intradetrusor injections of botulinum toxin for human detrusor overactivity. J Urol. 174, 977-982; discussion 982-973. doi: 910.1097/1001.ju.0000169481.0000142259.0000169454.

Araque, A., Li, N., Doyle, R.T., Haydon, P.G., 2000. SNARE protein-dependent glutamate release from astrocytes. J. Neurosci. 20, 666-673.

Arnon, S.S., Schechter, R., Inglesby, T.V., Henderson, D.A., Bartlett, J.G., Ascher, M.S., Eitzen, E., Fine, A.D., Hauer, J., Layton, M., Lillibridge, S., Osterholm, M.T., O'Toole, T., Parker, G., Perl, T.M., Russell, P.K., Swerdlow, D.L., Tonat, K., 2001. Botulinum toxin as a biological weapon: medical and public health management. JAMA 285, 1059-1070.

Ashkenazi, A., Blumenfeld, A., 2013. OnabotulinumtoxinA for the treatment of headache. Headache. 53, 54-61. doi: 10.1111/head.12185.

Ashton, A.C., Dolly, J.O., 1988. Characterization of the inhibitory action of botulinum neurotoxin type $A$ on the release of several transmitters from rat cerebrocortical synaptosomes. J Neurochem 50, 1808-1816.

Bach-Rojecky, L., Lackovic, Z., 2009. Central origin of the antinociceptive action of botulinum toxin type A. Pharmacol Biochem Behav. 94, 234-238. doi: 210.1016/j.pbb.2009.1008.1012. Epub 2009 Sep 1012.

Baldwin, M.R., Barbieri, J.T., 2009. Association of botulinum neurotoxins with synaptic vesicle protein complexes. Toxicon 54, 570-574.

Barash, J.R., Arnon, S.S., 2014. A Novel Strain of Clostridium botulinum That Produces Type B and Type H Botulinum Toxins. J Infect Dis. 209, 183-191. doi: 110.1093/infdis/jit1449. Epub 2013 Oct 1097.

Bartholome, O., Van den Ackerveken, P., Sanchez Gil, J., de la Brassinne Bonardeaux, O., Leprince, P., Franzen, R., Rogister, B., 2017. Puzzling Out Synaptic Vesicle 2 Family Members Functions. Front Mol Neurosci. 10:148., 10.3389/fnmol.2017.00148. eCollection 02017.

Benoit, R.M., Frey, D., Hilbert, M., Kevenaar, J.T., Wieser, M.M., Stirnimann, C.U., McMillan, D., Ceska, T., Lebon, F., Jaussi, R., Steinmetz, M.O., Schertler, G.F., Hoogenraad, C.C., Capitani, G., Kammerer, R.A., 2014. Structural basis for recognition of synaptic vesicle protein 2C by botulinum neurotoxin A. Nature. 505, 108-111. doi: 110.1038/nature12732. Epub 12013 Nov 12717.

Black, J.D., Dolly, J.O., 1986a. Interaction of 125I-labeled botulinum neurotoxins with nerve terminals. I. Ultrastructural autoradiographic localization and quantitation of distinct membrane acceptors for types A and B on motor nerves. J Cell Biol. 103, 521-534. doi: 510.1083/jcb.1103.1082.1521.

Black, J.D., Dolly, J.O., 1986b. Interaction of 125I-labeled botulinum neurotoxins with nerve terminals. II. Autoradiographic evidence for its uptake into motor nerves by acceptormediated endocytosis. J Cell Biol. 103, 535-544. doi: 510.1083/jcb.1103.1082.1535.

Black, J.D., Dolly, J.O., 1987. Selective location of acceptors for botulinum neurotoxin A in the central and peripheral nervous systems. Neuroscience 23, 767-779.

Bonventre, P.F., 1979. Absorption of botulinal toxin from the gastrointestinal tract. Rev. Infect. Dis. 1, 663-667. 
Breen, L.T., Smyth, L.M., Yamboliev, I.A., Mutafova-Yambolieva, V.N., 2006. beta-NAD is a novel nucleotide released on stimulation of nerve terminals in human urinary bladder detrusor muscle. Am J Physiol Renal Physiol 290, F486-495.

Breidenbach, M.A., Brunger, A.T., 2005. 2.3 A crystal structure of tetanus neurotoxin light chain. Biochemistry 44, 7450-7457.

Brunt, J., Carter, A.T., Stringer, S.C., Peck, M.W., 2018. Identification of a novel botulinum neurotoxin gene cluster in Enterococcus. FEBS Lett 592, 310-317.

Buckley, K., Kelly, R.B., 1985. Identification of a transmembrane glycoprotein specific for secretory vesicles of neuronal and endocrine cells. J. Cell Biol. 100, 1284-1294.

Bullens, R.W., O'Hanlon, G.M., Wagner, E., Molenaar, P.C., Furukawa, K., Furukawa, K., Plomp, J.J., Willison, H.J., 2002. Complex gangliosides at the neuromuscular junction are membrane receptors for autoantibodies and botulinum neurotoxin but redundant for normal synaptic function. J Neurosci. 22, 6876-6884. doi: 20026691.

Burgen, A.S., Dickens, F., Zatman, L.J., 1949. The action of botulinum toxin on the neuromuscular junction. J Physiol 109, 10-24.

Caleo, M., Restani, L., 2018. Direct central nervous system effects of botulinum neurotoxin. Toxicon. 147:68-72., 10.1016/j.toxicon.2017.1010.1027. Epub 2017 Oct 1031.

Carpenter, F.G., 1967. Motor responses of the urinary bladder and skeletal muscle in botulinum intoxicated rats. J Physiol. 188, 1-11. doi: 10.1113/jphysiol.1967.sp008119.

Chancellor, M.B., Fowler, C.J., Apostolidis, A., de Groat, W.C., Smith, C.P., Somogyi, G.T., Aoki, K.R., 2008. Drug Insight: biological effects of botulinum toxin A in the lower urinary tract. Nat Clin Pract Urol. 5, 319-328. doi: 310.1038/ncpuro1124. Epub 2008 May 1036.

Chancellor, M.B., Yoshimura, N., 2004. Neurophysiology of stress urinary incontinence. Rev Urol 6, S19-28.

Chapman, E.R., 2008. How does synaptotagmin trigger neurotransmitter release? Annu Rev Biochem 77:615-41., 10.1146/annurev.biochem.1177.062005.101135.

Chau, Y.P., Lu, K.S., 1996. Differential permeability of blood microvasculatures in various sympathetic ganglia of rodents. Anat Embryol (Berl). 194, 259-269. doi: 210.1007/bf00187137.

Cisterna, B.A., Cardozo, C., Saez, J.C., 2014. Neuronal involvement in muscular atrophy. Front Cell Neurosci. 8:405., 10.3389/fncel.2014.00405. eCollection 02014.

Coelho, A., Cruz, F., Cruz, C.D., Avelino, A., 2012a. Effect of onabotulinumtoxinA on intramural parasympathetic ganglia: an experimental study in the guinea pig bladder. J Urol. 187, 1121-1126. doi: 1110.1016/j.juro.2011.1110.1130. Epub 2012 Jan 1121.

Coelho, A., Cruz, F., Cruz, C.D., Avelino, A., 2012b. Spread of onabotulinumtoxinA after bladder injection. Experimental study using the distribution of cleaved SNAP-25 as the marker of the toxin action. Eur Urol. 61, 1178-1184. doi: 1110.1016/j.eururo.2012.1101.1046. Epub 2012 Feb 1171.

Coelho, A., Dinis, P., Pinto, R., Gorgal, T., Silva, C., Silva, A., Silva, J., Cruz, C.D., Cruz, F., Avelino, A., 2010. Distribution of the high-affinity binding site and intracellular target of botulinum toxin type $A$ in the human bladder. Eur Urol. 57, 884-890. doi: 810.1016/j.eururo.2009.1012.1022. Epub 2009 Dec 1030.

Coelho, A., Oliveira, R., Cruz, F., Cruz, C.D., 2016. Impairment of sensory afferents by intrathecal administration of botulinum toxin $A$ improves neurogenic detrusor overactivity in chronic spinal cord injured rats. Exp Neurol. 285, 159-166. doi: 110.1016/j.expneurol.2016.1005.1029. Epub 2016 May 1025. 
Coelho, A., Oliveira, R., Rossetto, O., Cruz, C.D., Cruz, F., Avelino, A., 2014. Intrathecal administration of botulinum toxin type $A$ improves urinary bladder function and reduces pain in rats with cystitis. Eur J Pain 23, 513.

Colasante, C., Rossetto, O., Morbiato, L., Pirazzini, M., Molgo, J., Montecucco, C., 2013. Botulinum Neurotoxin Type $A$ is Internalized and Translocated from Small Synaptic Vesicles at the Neuromuscular Junction. Mol Neurobiol 48, 120-127.

Connan, C., Varela-Chavez, C., Mazuet, C., Molgo, J., Haustant, G.M., Disson, O., Lecuit, M., Vandewalle, A., Popoff, M.R., 2016. Translocation and dissemination to target neurons of botulinum neurotoxin type B in the mouse intestinal wall. Cell Microbiol 18, 282301.

Connan, C., Voillequin, M., Varela Chavez, C., Mazuet, C., Leveque, C., Vitry, S., Vandewalle, A., Popoff, M.R., 2017. Botulinum Neurotoxin Type B Uses a Distinct Entry Pathway Mediated By Cdc42 Into Intestinal Cells Versus Neuronal Cells. Cell Microbiol 19, e12738.

Contreras, E., Masuyer, G., Qureshi, N., Chawla, S., Dhillon, H.S., Lee, H.L., Chen, J., Stenmark, P., Gill, S.S., 2019. A neurotoxin that specifically targets Anopheles mosquitoes. Nat Commun. 10, 2869. doi: 2810.1038/s41467-41019-10732-w.

Couesnon, A., Molgo, J., Connan, C., Popoff, M.R., 2012. Preferential entry of botulinum neurotoxin A Hc domain trhough intestinal crypt cells and targeting to cholinergic neurons of the mouse intestine. PLoS Pathog 8, e1002583.

Couesnon, A., Shimizu, T., Popoff, M.R., 2009. Differential entry of botulinum neurotoxin A into neuronal and intestinal cells. Cell Microbiol 11, 289-308.

Cui, M., Khanijou, S., Rubino, J., Aoki, K.R., 2004. Subcutaneous administration of botulinum toxin A reduces formalin-induced pain. Pain 107, 125-133.

Dardou, D., Dassesse, D., Cuvelier, L., Deprez, T., De Ryck, M., Schiffmann, S.N., 2011. Distribution of SV2C mRNA and protein expression in the mouse brain with a particular emphasis on the basal ganglia system. Brain Res. 1367:130-45., 10.1016/j.brainres.2010.1009.1063. Epub 2010 Sep 1022.

Desplantes, R., Leveque, C., Muller, B., Lotierzo, M., Ferracci, G., Popoff, M., Seagar, M., Mamoun, R., El Far, O., 2017. Affinity biosensors using recombinant native membrane proteins displayed on exosomes: application to botulinum neurotoxin B receptor. Sci Rep. 7, 1032. doi: 1010.1038/s41598-41017-01198-41591.

Dickson, E.C., Shevky, E., 1923. Botulism. Studies on the Manner in Which the Toxin of Clostridium Botulinum Acts Upon the Body : li. The Effect Upon the Voluntary Nervous System. J Exp Med. 38, 327-346.

Do, T.P., Hvedstrup, J., Schytz, H.W., 2018. Botulinum toxin: A review of the mode of action in migraine. Acta Neurol Scand. 137, 442-451. doi: 410.1111/ane.12906. Epub 12018 Feb 12906.

Dolly, J.O., Black, J., Williams, R.S., Melling, J., 1984. Acceptors for botulinum neurotoxin reside on motor nerve terminals and mediate its internalization. Nature (London) 307, 457-460.

Dong, M., Liu, H., Tepp, W.H., Johnson, E.A., Janz, R., Chapman, E.R., 2008. Glycosylated SV2A and SV2B mediate the entry of botulinum neurotoxin $E$ into neurons. Mol Biol Cell 19, 5226-5237.

Dong, M., Yeh, F., Tepp, W.H., Dean, C., Johnson, E.A., Janz, R., Chapman, E.R., 2006. SV2 Is the Protein Receptor for Botulinum Neurotoxin A. Science 312, 592-596. 
Dover, N., Barash, J.R., Hill, K.K., Xie, G., Arnon, S.S., 2014. Molecular characterization of a novel botulinum neurotoxin type $H$ gene. J Infect Dis. 209, 192-202. doi: 110.1093/infdis/jit1450. Epub 2013 Oct 1097.

Dressler, D., 2013. Botulinum toxin therapy: its use for neurological disorders of the autonomic nervous system. J Neurol. 260, 701-713. doi: 710.1007/s00415-0001206615-00412. Epub 02012 Aug 00410.

Dressler, D., Benecke, R., 2007. Pharmacology of therapeutic botulinum toxin preparations. Disabil Rehabil 29, 1761-1768.

Duggan, M.J., Quinn, C.P., Chaddock, J.A., Purkiss, J.R., Alexander, F.C., Doward, S., Fooks, S.J., Friis, L.M., Hall, Y.H., Kirby, E.R., Leeds, N., Moulsdale, H.J., Dickenson, A., Green, G.M., Rahman, W., Suzuki, R., Shone, C.C., Foster, K.A., 2002. Inhibition of release of neurotransmitters from rat dorsal root ganglia by a novel conjugate of a Clostridium botulinum toxin A endopeptidase fragment and Erythrina cristagalli lectin. J Biol Chem 277, 34846-34852.

Dunant, Y., Esquerda, J.E., Loctin, F., Marsal, J., Muller, D., 1987. Botulinum toxin inhibits quantal acetylcholine release and energy metabolism in the Torpedo electric organ. J Physiol 385, 677-692.

Dunn, A.R., Hoffman, C.A., Stout, K.A., Ozawa, M., Dhamsania, R.K., Miller, G.W., 2019. Immunochemical analysis of the expression of SV2C in mouse, macaque and human brain. Brain Res. 1702:85-95., 10.1016/j.brainres.2017.1012.1029. Epub 2017 Dec 1021.

Durham, P.L., Cady, R., Cady, R., 2004. Regulation of calcitonin gene-related peptide secretion from trigeminal nerve cells by botulinum toxin type $A$ : implications for migraine therapy. Headache 44, 35-42; discussion 42-33.

Eleopra, R., Montecucco, C., Devigili, G., Lettieri, C., Rinaldo, S., Verriello, L., Pirazzini, M., Caccin, P., Rossetto, O., 2013. Botulinum neurotoxin serotype D is poorly effective in humans: an in vivo electrophysiological study. Clin Neurophysiol. 124, 999-1004. doi: 1010.1016/j.clinph.2012.1011.1004. Epub 2012 Dec 1013.

Elliott, M., Favre-Guilmard, C., Liu, S.M., Maignel, J., Masuyer, G., Beard, M., Boone, C., Carre, D., Kalinichev, M., Lezmi, S., Mir, I., Nicoleau, C., Palan, S., Perier, C., Raban, E., Zhang, S., Dong, M., Stenmark, P., Krupp, J., 2019. Engineered botulinum neurotoxin B with improved binding to human receptors has enhanced efficacy in preclinical models. Sci Adv. 5, eaau7196. doi: 7110.1126/sciadv.aau7196. eCollection 2019 Jan.

Emsley, P., Fotinou, C., Black, I., Fairweather, N.F., Charles, I.G., Watts, C., Hewitt, E., Isaacks, N.W., 2000. The structures of the Hc fragment of Tetanus Toxin with carbohydrate subunit complexes provide insight into ganglioside binding. J. Biol. Chem. 275, 88898894.

Fan, C., Chu, X., Wang, L., Shi, H., Li, T., 2017. Botulinum toxin type A reduces TRPV1 expression in the dorsal root ganglion in rats with adjuvant-arthritis pain. Toxicon. 133:116-122., 10.1016/j.toxicon.2017.1005.1001. Epub 2017 May 1013.

Fenicia, L., Anniballi, F., 2009. Infant botulism. Ann Ist Super Sanita 45, 134-146.

Ferrari, E., Gu, C., Niranjan, D., Restani, L., Rasetti-Escargueil, C., Obara, I., Geranton, S.M., Arsenault, J., Goetze, T.A., Harper, C.B., Nguyen, T.H., Maywood, E., O'Brien, J., Schiavo, G., Wheeler, D.W., Meunier, F.A., Hastings, M., Edwardson, J.M., Sesardic, D., Caleo, M., Hunt, S.P., Davletov, B., 2013. Synthetic self-assembling clostridial chimera for modulation of sensory functions. Bioconjug Chem. 24, 1750-1759. doi: 1710.1021/bc4003103. Epub 4002013 Sep 4003120. 
Filipovic, B., Matak, I., Bach-Rojecky, L., Lackovic, Z., 2012. Central action of peripherally applied botulinum toxin type $A$ on pain and dural protein extravasation in rat model of trigeminal neuropathy. PLoS One 7, e29803. doi: 29810.21371/journal.pone.0029803. Epub 0022012 Jan 0029804.

Filippi, G.M., Errico, P., Santarelli, R., Bagolini, B., Manni, E., 1993. Botulinum A toxin effects on rat jaw muscle spindles

. Acta Otolaryngol. 113, 400-404.

Flores, A., Ramirez-Franco, J., Desplantes, R., Debreux, K., Ferracci, G., Wernert, F., Blanchard, M.P., Maulet, Y., Youssouf, F., Sangiardi, M., Iborra, C., Popoff, M.R., Seagar, M., Fantini, J., Leveque, C., El Far, O., 2019. Gangliosides interact with synaptotagmin to form the high-affinity receptor complex for botulinum neurotoxin $B$. Proc Natl Acad Sci U S A. 116, 18098-18108. doi: 18010.11073/pnas.1908051116. Epub 1908052019 Aug 1908051120.

Foran, P.G., Mohammed, N., Lisk, G.O., Nagwaney, S., Lawrence, G.W., Johnson, E., Smith, L., Aoki, K.R., Dolly, O.J., 2003. Evaluation of the therapeutic usefulness of botulinum neurotoxin B, C1, E and F compared with the long lasting type A. J. Biol. Chem. 278, 1363-1371.

Fotinou, C., Emsley, P., Black, I., Ando, H., Ishida, H., Kiso, M., Sinha, K.A., Fairweather, N.F., Isaacs, N.W., 2001. The crystal structure of Tetanus Toxin Hc fragment complexed with a synthetic GT1b analogue suggests cross-linking between ganglioside receptors and the toxin. J. Biol. Chem. 276, 3274-3281.

Fox, C.K., Keet, C.A., Strober, J.B., 2005. Recent advances in infant botulism. Pediatr Neurol 32, 149-154.

Fu, Z., Chen, C., Barbieri, J.T., Kim, J.J., Baldwin, M.R., 2009. Glycosylated SV2 and gangliosides as dual receptors for botulinum neurotoxin serotype F. Biochemistry 48, 5631-5641.

Fu, Z., Chen, S., Baldwin, M.R., Boldt, G.E., Crawford, A., Janda, K.D., Barbieri, J.T., Kim, J.J., 2006. Light chain of botulinum neurotoxin serotype $A$ : structural resolution of a catalytic intermediate. Biochemistry 45, 8903-8911.

Fujinaga, Y., Popoff, M.R., 2018. Translocation and dissemination of botulinum neurotoxin from the intestinal tract. Toxicon 147, 13-18.

Furness, J.B., Callaghan, B.P., Rivera, L.R., Cho, H.J., 2014. The enteric nervous system and gastrointestinal innervation: integrated local and central control. Adv Exp Med Biol 817:39-71., 10.1007/1978-1001-4939-0897-1004_1003.

Gershon, M.D., 2013. 5-Hydroxytryptamine (serotonin) in the gastrointestinal tract. Curr Opin Endocrinol Diabetes Obes. 20, 14-21. doi: 10.1097/MED.1090b1013e32835bc32703.

Gong, Y., Tagawa, Y., Lunn, M.P., Laroy, W., Heffer-Lauc, M., Li, C.Y., Griffin, J.W., Schnaar, R.L., Sheikh, K.A., 2002. Localization of major gangliosides in the PNS: implications for immune neuropathies. Brain. 125, 2491-2506.

Habermann, E., Dreyer, F., 1986. Clostridial neurotoxins: handling and action at the cellular and molecular level. Cur. Top. Microbiol. Immunol. 129, 93-179.

Hanchanale, V.S., Rao, A.R., Martin, F.L., Matanhelia, S.S., 2010. The unusual history and the urological applications of botulinum neurotoxin. Urol Int 85, 125-130.

Hassan, S.M., Jennekens, F.G., Wieneke, G., Veldman, H., 1994. Calcitonin gene-related peptide-like immunoreactivity, in botulinum toxin-paralysed rat muscles. Neuromuscul Disord 4, 489-496. 
Holmgren, J., Lonnroth, I., Mansson, J., Svennerholm, L., 1975. Interaction of cholera toxin and membrane GM1 ganglioside of small intestine. Proc Natl Acad Sci U S A. 72, 25202524. doi: 2510.1073/pnas.2572.2527.2520.

Humeau, Y., Doussau, F., Grant, N.J., Poulain, B., 2000. How botulinum and tetanus neurotoxins block neurotransmitter release. Biochimie 82, 427-446.

Ikeda, Y., Zabbarova, I.V., Birder, L.A., de Groat, W.C., McCarthy, C.J., Hanna-Mitchell, A.T., Kanai, A.J., 2012. Botulinum neurotoxin serotype A suppresses neurotransmitter release from afferent as well as efferent nerves in the urinary bladder. Eur Urol. 62, 1157-1164. doi: 1110.1016/j.eururo.2012.1103.1031. Epub 2012 Mar 1123.

Imamura, K., Spriggs, D., Ohno, T., Kufe, D., 1989. Effects of botulinum toxin type D on secretion of tumor necrosis factor from human monocytes. Mol Cell Biol. 9, 22392243. doi: $2210.1128 / \mathrm{mcb} .2239 .2235 .2239$.

Iwamori, M., Shimomura, J., Tsuyuhara, S., Nagai, Y., 1984. Gangliosides of various rat tissues: distribution of ganglio-N-tetraose-containing gangliosides and tissuecharacteristic composition of gangliosides. J Biochem. 95, 761-770.

Jahn, R., Fasshauer, D., 2012. Molecular machines governing exocytosis of synaptic vesicles. Nature. 490, 201-207. doi: 210.1038/nature11320.

Jankovic, J., 2017. Botulinum toxin: State of the art. Mov Disord 32, 1131-1138.

Janz, R., Südhof, T.C., 1999. SV2C is a synaptic vesicle protein with an unusually restricted localization: anatomy of a synaptic vesicle protein family. Neurosci. 94, 1279-1290.

Jin, R., Rummel, A., Binz, T., Brunger, A.T., 2006. Botulinum neurotoxin B recognizes its protein receptor with high affinity and specificity. Nature 444, 1092-1095.

Kamata, Y., Kimura, Y., Hiroi, T., Sakaguchi, G., Kozaki, S., 1993. Purification and characterization of the ganglioside-binding fragment of Clostridium botulinum type $E$ neurotoxin. Biochim Biophys Acta. 1156, 213-218.

Karalewitz, A.P., Fu, Z., Baldwin, M.R., Kim, J.J., Barbieri, J.T., 2012. Botulinum neurotoxin serotype $\mathrm{C}$ associates with dual ganglioside receptors to facilitate cell entry. J Biol Chem. 287, 40806-40816. doi: 40810.41074/jbc.M40112.404244. Epub 402012 Oct 404241.

Karalewitz, A.P., Kroken, A.R., Fu, Z., Baldwin, M.R., Kim, J.J., Barbieri, J.T., 2010. Identification of a unique ganglioside binding loop within botulinum neurotoxins $\mathrm{C}$ and D-SA. Biochemistry 49, 8117-8126.

Kiernan, J.A., 1996. Vascular permeability in the peripheral autonomic and somatic nervous systems: controversial aspects and comparisons with the blood-brain barrier. Microsc Res Tech. 35, 122-136. doi: 110.1002/(SICI)10970029(19961001)19961035:19961002<19961122::AIDJEMT19961003>19961003.19961000.CO;19961002-S.

Kitamura, M., Takamiya, K., Aizawa, S., Furukawa, K., 1999. Gangliosides are the binding substances in neural cells for tetanus and botulinum toxins in mice. Biochim. Biophys. Acta 1441, 1-3.

Kitamura, Y., Matsuka, Y., Spigelman, I., Ishihara, Y., Yamamoto, Y., Sonoyama, W., Kamioka, H., Yamashiro, T., Kuboki, T., Oguma, K., 2009. Botulinum toxin type a (150 kDa) decreases exaggerated neurotransmitter release from trigeminal ganglion neurons and relieves neuropathy behaviors induced by infraorbital nerve constriction. Neuroscience. 159, 1422-1429. doi: 1410.1016/j.neuroscience.2009.1401.1066. Epub 2009 Feb 1423. 
Kolter, T., 2012. Ganglioside biochemistry. ISRN Biochem. 2012:506160., 10.5402/2012/506160. eCollection 502012.

Kroken, A.R., Karalewitz, A.P., Fu, Z., Baldwin, M.R., Kim, J.J., Barbieri, J.T., 2011a. Unique ganglioside binding by botulinum neurotoxins $C$ and D-SA. Febs J 278, 4486-4496.

Kroken, A.R., Karalewitz, A.P., Fu, Z., Kim, J.J., Barbieri, J.T., 2011b. Novel gangliosidemediated entry of botulinum neurotoxin serotype D into neurons. J Biol Chem 286, 26828-26837.

Kumaran, D., Eswaramoorthy, S., Furey, W., Navaza, J., Sax, M., Swaminathan, S., 2009. Domain organization in Clostridium botulinum neurotoxin type $E$ is unique: its implication in faster translocation. J Mol Biol 386, 233-245.

Lacy, D.B., Stevens, R.C., 1999. Sequence homology and structural analysis of the clostridial neurotoxins. J. Mol. Biol. 291, 1091-1104.

Lacy, D.B., Tepp, W., Cohen, A.C., Das Gupta, B.R., Stevens, R.C., 1998. Crystal structure of botulinum neurotoxin type A and implications for toxicity. Nature Struct. Biol. 5, 898902.

Lawrence, G.W., Aoki, K.R., Dolly, J.O., 2010. Excitatory cholinergic and purinergic signaling in bladder are equally susceptible to botulinum neurotoxin a consistent with co-release of transmitters from efferent fibers. J Pharmacol Exp Ther. 334, 1080-1086. doi: 1010.1124/jpet.1110.169342. Epub 162010 Jun 169324.

Lee, K., Zhong, X., Gu, S., Kruel, A.M., Dorner, M.B., Perry, K., Rummel, A., Dong, M., Jin, R., 2014. Molecular basis for disruption of E-cadherin adhesion by botulinum neurotoxin $A$ complex. Science. 344, 1405-1410. doi: 1410.1126/science.1253823.

Li, Z., Chalazonitis, A., Huang, Y.Y., Mann, J.J., Margolis, K.G., Yang, Q.M., Kim, D.O., Cote, F., Mallet, J., Gershon, M.D., 2011. Essential roles of enteric neuronal serotonin in gastrointestinal motility and the development/survival of enteric dopaminergic neurons. J Neurosci. 31, 8998-9009. doi: 8910.1523/JNEUROSCI.6684-8910.2011.

Loiseau, K., Scheiber-Nogueira, M.C., Tilikete, C., Vighetto, A., Rode, G., 2010. Bladder paralysis due to foodborne botulinum toxin type B. Urol J. 7, 63-65.

Lopez, P.H.H., Baez, B.B., 2018. Gangliosides in Axon Stability and Regeneration. Prog Mol Biol Transl Sci 156:383-412., 10.1016/bs.pmbts.2018.1003.1001. Epub 2018 Apr 1010.

Lucioni, A., Bales, G.T., Lotan, T.L., McGehee, D.S., Cook, S.P., Rapp, D.E., 2008. Botulinum toxin type $A$ inhibits sensory neuropeptide release in rat bladder models of acute injury and chronic inflammation. BJU Int 101, 366-370.

Mahrhold, S., Rummel, A., Bigalke, H., Davletov, B., Binz, T., 2006. The synaptic vesicle protein $2 \mathrm{C}$ mediates the uptake of botulinum neurotoxin $\mathrm{A}$ into phrenic nerves. FEBS Lett 580, 2011-2014.

Mahrhold, S., Strotmeier, J., Garcia-Rodriguez, C., Lou, J., Marks, J.D., Rummel, A., Binz, T., 2013. Identification of the SV2 protein receptor-binding site of botulinum neurotoxin type E. Biochem J 453, 37-47.

Maisey, E.A., Wadsworth, J.D., Poulain, B., Shone, C.C., Melling, J., Gibbs, P., Tauc, L., Dolly, J.O., 1988. Involvement of the constituent chains of botulinum neurotoxins $A$ and $B$ in the blockade of neurotransmitter release. Eur J Biochem 177, 683-691.

Maksymowych, A.B., Rienhard, M., Malizio, C.J., Goodnough, M.C., Johnson, E.A., Simpson, L.L., 1999. Pure botulinum neurotoxin is absorbed from the stomach and small intestine and produces peripheral neuromuscular blockade. Infect. Immun. 67, 47084712. 
Mangione, A.S., Obara, I., Maiaru, M., Geranton, S.M., Tassorelli, C., Ferrari, E., Leese, C., Davletov, B., Hunt, S.P., 2016. Nonparalytic botulinum molecules for the control of pain. Pain. 157, 1045-1055. doi: 1010.1097/j.pain.0000000000000478.

Mansfield, M.J., Wentz, T.G., Zhang, S., Lee, E.J., Dong, M., Sharma, S.K., Doxey, A.C., 2019. Bioinformatic discovery of a toxin family in Chryseobacterium piperi with sequence similarity to botulinum neurotoxins. Sci Rep. 9, 1634. doi: 1610.1038/s41598-4101837647-41598.

Marinelli, S., Vacca, V., Ricordy, R., Uggenti, C., Tata, A.M., Luvisetto, S., Pavone, F., 2012. The analgesic effect on neuropathic pain of retrogradely transported botulinum neurotoxin A involves Schwann cells and astrocytes. PLoS One 7, e47977. doi: 47910.41371/journal.pone.0047977. Epub 0042012 Oct 0047924.

Masuyer, G., Conrad, J., Stenmark, P., 2017. The structure of the tetanus toxin reveals $\mathrm{pH}$ mediated domain dynamics. EMBO Rep 18, 1306-1317.

Matak, I., Rossetto, O., Lackovic, Z., 2014. Botulinum toxin type A selectivity for certain types of pain is associated with capsaicin-sensitive neurons. Pain. 155, 1516-1526. doi: 1510.1016/j.pain.2014.1504.1027. Epub 2014 May 1512.

Matsumura, T., Jin, Y., Kabumoto, Y., Takegahara, Y., Oguma, K., Lencer, W.I., Fujinaga, Y., 2008. The HA proteins of botulinum toxin disrupt intestinal epithelial intercellular junctions to increase toxin absorption. Cell Microbiol 10, 355-364.

Matsumura, T., Sugawara, Y., Yutani, M., Amatsu, S., Yagita, H., Kohda, T., Fukuoka, S., Nakamura, Y., Fukuda, S., Hase, K., Ohno, H., Fujinaga, Y., 2015. Botulinum toxin A complex exploits intestinal $M$ cells to enter the host and exert neurotoxicity. Nat Commun 6, 6255.

May, A.J., Whaler, B.C., 1958. The absorption of Clostridium botulinum type Atoxin from the alimentary canal. Br. J. Exp. Path. 39, 307-316.

McMahon, H.T., Foran, P., Dolly, J.O., Verhage, M., Wiegant, V.M., Nicholls, D.G., 1992. Tetanus toxin and botulinum toxins type $A$ and $B$ inhibit glutamate, gammaaminobutyric acid, aspartate, and met-enkephalin release from synaptosomes. Clues to the locus of action. J Biol Chem 267, 21338-21343.

Meng, J., Dolly, J.O., Wang, J., 2014. Selective Cleavage of SNAREs in Sensory Neurons Unveils Protein Complexes Mediating Peptide Exocytosis Triggered by Different Stimuli. Mol Neurobiol, 8.

Merz, B., Bigalke, H., Stoll, G., Naumann, M., 2003. Botulism type B presenting as pure autonomic dysfunction. Clin Auton Res 13, 337-338.

Meunier, F.A., Colasante, C., Faille, L., Gastard, M., Molgo, J., 1996. Upregulation of calcitonin gene-related peptide at mouse motor nerve terminals poisoned with botulinum type-A toxin. Pflugers Arch 431, R297-298.

Molgo, J., Comella, J.X., Angaut-Petit, D., Pecot-Dechavassine, M., Tabti, N., Faille, L., Mallart, A., Thesleff, S., 1990. Presynaptic actions of botulinal neurotoxins at vertebrate neuromuscular junctions. J Physiol (Paris) 84, 152-166.

Montal, M., 2010. Botulinum Neurotoxin: A Marvel of Protein Design. Annu Rev Biochem 79, 591-617.

Montecucco, C., 1986. How do tetanus and botulinum toxins to neuronal membranes? TIBS 11, 314-317.

Morris, J.L., Jobling, P., Gibbins, I.L., 2002. Botulinum neurotoxin A attenuates release of norepinephrine but not NPY from vasoconstrictor neurons. Am J Physiol Heart Circ Physiol 283, H2627-2635. 
Najib, A., Pelliccioni, P., Gil, C., Aguilera, J., 1999. Clostridium neurotoxins influence serotonin uptake and release differently in rat brain synaptosomes. J Neurochem 72, 1991-1998.

Naumann, M., Dressler, D., Hallett, M., Jankovic, J., Schiavo, G., Segal, K.R., Truong, D., 2013. Evidence-based review and assessment of botulinum neurotoxin for the treatment of secretory disorders. Toxicon. 67:141-52., 10.1016/j.toxicon.2012.1010.1020. Epub 2012 Nov 1023.

Neale, E.A., Bowers, L.M., Jia, M., Bateman, K.E., Williamson, L.C., 1999. Botulinum neurotoxin A blocks synaptic vesicle exocytosis but not endocytosis at the nerve terminal. J Cell Biol 147, 1249-1260.

Nishiki, T., Kamata, Y., Nemoto, Y., Omori, A., Ito, T., Takahashi, M., Kozaki, S., 1994. Identification of protein receptor for Clostridium botulinum type $\mathrm{B}$ neurotoxin in rat brain synaptosomes. J. Biol. Chem. 269, 10498-10503.

Nishiki, T., Tokuyama, Y., Kamata, Y., Nemoto, Y., Yoshida, A., Sato, K., Sekigichi, M., Taakahashi, M., Kozaki, S., 1996. The high-affinity of Clostridium botulinum type B neurotoxin to synaptotagmin II associated with gangliosides $G_{T 1 B} / G_{D 1 a}$. FEBS Lett. 378, 253-257.

Ochanda, J.O., Syuto, B., Ohishi, I., Naiki, M., Kubo, S., 1986. Binding of Clostridium botulinum neurotoxin to gangliosides. J Biochem. 100, 27-33.

Pang, Z.P., Melicoff, E., Padgett, D., Liu, Y., Teich, A.F., Dickey, B.F., Lin, W., Adachi, R., Sudhof, T.C., 2006. Synaptotagmin-2 is essential for survival and contributes to Ca2+ triggering of neurotransmitter release in central and neuromuscular synapses. J Neurosci. 26, 13493-13504. doi: 13410.11523/JNEUROSCI.13519-13406.12006.

Park, J., Park, H.J., 2017. Botulinum Toxin for the Treatment of Neuropathic Pain. Toxins (Basel). 9(9). toxins9090260. doi: 9090210.9093390/toxins9090260.

Peck, M.W., Smith, T.J., Anniballi, F., Austin, J.W., Bano, L., Bradshaw, M., Cuervo, P., Cheng, L.W., Derman, Y., Dorner, B.G., Fisher, A., Hill, K.K., Kalb, S.R., Korkeala, H., Lindstrom, M., Lista, F., Luquez, C., Mazuet, C., Pirazzini, M., Popoff, M.R., Rossetto, O., Rummel, A., Sesardic, D., Singh, B.R., Stringer, S.C., 2017. Historical Perspectives and Guidelines for Botulinum Neurotoxin Subtype Nomenclature. Toxins (Basel) 9, 38.

Pellett, S., Tepp, W.H., Bradshaw, M., Kalb, S.R., Dykes, J.K., Lin, G., Nawrocki, E.M., Pier, C.L., Barr, J.R., Maslanka, S.E., Johnson, E.A., 2016. Purification and Characterization of Botulinum Neurotoxin FA from a Genetically Modified Clostridium botulinum Strain. mSphere. 1(1). mSphere00100-00115. doi: 00110.01128/mSphere.00100-00115. eCollection 02016 Jan-Feb.

Pellett, S., Tepp, W.H., Johnson, E.A., 2019. Botulinum neurotoxins A, B, C, E, and F preferentially enter cultured human motor neurons compared to other cultured human neuronal populations. FEBS Lett, 13508.

Peng, L., Berntsson, R.P., Tepp, W.H., Pitkin, R.M., Johnson, E.A., Stenmark, P., Dong, M., 2012. Botulinum neurotoxin $D-C$ uses synaptotagmin $I / I I$ as receptors and human synaptotagmin II is not an effective receptor for type B, D-C, and G toxins. J Cell Sci 125, 3233-3242.

Peng, L., Tepp, W.H., Johnson, E.A., Dong, M., 2011. Botulinum neurotoxin D uses synaptic vesicle protein SV2 and gangliosides as receptors. PLoS Pathog 7, e1002008.

Penner, R., Neher, E., Dreyer, F., 1986. Intracellularly injected tetanus toxin inhibits exocytosis in bovine adrenal chromaffin cells. Nature 324, 76-78. 
Pirazzini, M., Rossetto, O., 2017. Challenges in searching for therapeutics against Botulinum Neurotoxins. Expert Opin Drug Discov 12, 497-510.

Pirazzini, M., Rossetto, O., Eleopra, R., Montecucco, C., 2017. Botulinum Neurotoxins: Biology, Pharmacology, and Toxicology. Pharmacol Rev 69, 200-235.

Popoff, M.R., Connan, C., 2014. Absorption and transport of botulinum neurotoxins, in: Foster, K.A. (Ed.), Molecular Aspects of Botulinum Neurotoxin. Springer, New York, pp. 35-68.

Popoff, M.R., Marvaud, J.C., 1999. Structural and genomic features of clostridial neurotoxins, in: Alouf, J.E., Freer, J.H. (Eds.), The Comprehensive Sourcebook of Bacterial Protein Toxins, 2 ed. Academic Press, London, pp. 174-201.

Popoff, M.R., Poulain, B., 2010. Bacterial toxins and the nervous system: neurotoxins and multipotential toxins interacting with neuronal cells. Toxins (Basel). 2, 683-737. doi: 610.3390/toxins2040683. Epub 2042010 Apr 2040615.

Poulain, B., Molgo, J., Thesleff, S., 1995. Quantal neurotransmitter release and the clostridial neurotoxins' targets. Curr Top Microbiol Immunol 195, 243-255.

Poulain, B., Popoff, M.R., 2019. Why Are Botulinum Neurotoxin-Producing Bacteria So Diverse and Botulinum Neurotoxins So Toxic? Toxins (Basel). 11(1). toxins11010034. doi: $11010010.11013390 /$ toxins11010034.

Poulain, B., Popoff, M.R., Molgo, J., 2008. How do the botulinum neurotoxins block neurotransmitter release: from botulism to the molecular mechanism of action. Botulinum J. 1, 14-87.

Poulain, B., Tauc, L., Maisey, E.A., Wadsworth, J.D., Mohan, P.M., Dolly, J.O., 1988. Neurotransmitter release is blocked intracellularly by botulinum neurotoxin, and this requires uptake of both toxin polypeptides by a process mediated by the larger chain. Proc Natl Acad Sci U S A 85, 4090-4094.

Ramachandran, R., Yaksh, T.L., 2014. Therapeutic use of botulinum toxin in migraine: mechanisms of action. Br J Pharmacol. 171, 4177-4192. doi: 4110.1111/bph.12763.

Rapp, D.E., Turk, K.W., Bales, G.T., Cook, S.P., 2006. Botulinum toxin type A inhibits calcitonin gene-related peptide release from isolated rat bladder. J Urol 175, 1138-1142.

Regazzi, R., Sadoul, K., Meda, P., Kelly, R.B., Halban, P.A., Wollheim, C.B., 1996. Mutational analysis of VAMP domains implicated in Ca2+-induced insulin exocytosis. Embo J 15, 6951-6959.

Restani, L., Giribaldi, F., Manich, M., Bercsenyi, K., Menendez, G., Rossetto, O., Caleo, M., Schiavo, G., 2012a. Botulinum neurotoxins $A$ and $E$ undergo retrograde axonal transport in primary motor neurons. PLoS Pathog 8, e1003087.

Restani, L., Novelli, E., Bottari, D., Leone, P., Barone, I., Galli-Resta, L., Strettoi, E., Caleo, M., 2012b. Botulinum neurotoxin a impairs neurotransmission following retrograde transynaptic transport. Traffic 13, 1083-1089.

Romanov, A., Pokushalov, E., Ponomarev, D., Bayramova, S., Shabanov, V., Losik, D., Stenin, I., Elesin, D., Mikheenko, I., Strelnikov, A., Sergeevichev, D., Kozlov, B., Po, S.S., Steinberg, J.S., 2019. Long-term suppression of atrial fibrillation by botulinum toxin injection into epicardial fat pads in patients undergoing cardiac surgery: Three-year follow-up of a randomized study. Heart Rhythm. 16, 172-177. doi: 110.1016/j.hrthm.2018.1008.1019. Epub 2018 Nov 1017.

Rosales, R.L., Arimura, K., Takenaga, S., Osame, M., 1996. Extrafusal and intrafusal muscle effects in experimental botulinum toxin-A injection. Muscle Nerve 19, 488-496. 
Rosales, R.L., Dressler, D., 2010. On muscle spindles, dystonia and botulinum toxin. Eur J Neurol. 17, 71-80. doi: 10.1111/j.1468-1331.2010.03056.x.

Rosow, L.K., Strober, J.B., 2015. Infant botulism: review and clinical update. Pediatr Neurol $52,487-492$.

Rossetto, 0., 2018. The binding of botulinum neurotoxins to different peripheral neurons. Toxicon. 147:27-31., 10.1016/j.toxicon.2017.1010.1010. Epub 2017 Oct 1016.

Rossetto, O., Pirazzini, M., Montecucco, C., 2015. Current gaps in basic science knowledge of botulinum neurotoxin biological actions. Toxicon 107, 59-63.

Rossetto, O., Scorzeto, M., Megighian, A., Montecucco, C., 2013. Tetanus neurotoxin. Toxicon. 66:59-63., 10.1016/j.toxicon.2012.1012.1027. Epub 2013 Feb 1016.

Rummel, A., 2017. Two Feet on the Membrane: Uptake of Clostridial Neurotoxins. Curr Top Microbiol Immunol 406, 1-37.

Rummel, A., Eichner, T., Weil, T., Karnath, T., Gutcaits, A., Mahrhold, S., Sandhoff, K., Proia, R.L., Acharya, K.R., Bigalke, H., Binz, T., 2007. Identification of the protein receptor binding site of botulinum neurotoxins $B$ and $G$ proves the double-receptor concept. Proc Natl Acad Sci U S A 104, 359-364.

Rummel, A., Hafner, K., Mahrhold, S., Darashchonak, N., Holt, M., Jahn, R., Beermann, S., Karnath, T., Bigalke, H., Binz, T., 2009. Botulinum neurotoxins C, E and $F$ bind gangliosides via a conserved binding site prior to stimulation-dependent uptake with botulinum neurotoxin $\mathrm{F}$ utilising the three isoforms of SV2 as second receptor. J Neurochem 110, 1942-1954.

Rummel, A., Karnath, T., Henke, T., Bigalke, H., Binz, T., 2004a. Synaptotagmins I and II act as nerve cell receptors for botulinum neurotoxin G. J. Biol. Chem. 279, 30865-30870.

Rummel, A., Mahrhold, S., Bigalke, H., Binz, T., 2004b. The $\mathrm{H}_{\mathrm{cc}}$-domain of botulinum neurotoxins $A$ and $B$ exhibits a singular ganglioside binding site displaying serotype specific carbohydrate interaction. Mol. Microbiol. 51, 631-643.

Russell, F.A., King, R., Smillie, S.J., Kodji, X., Brain, S.D., 2014. Calcitonin gene-related peptide: physiology and pathophysiology. Physiol Rev. 94, 1099-1142. doi: 1010.1152/physrev.00034.02013.

Safarpour, Y., Jabbari, B., 2018. Botulinum toxin treatment of pain syndromes -an evidence based review. Toxicon. 147:120-128., 10.1016/j.toxicon.2018.1001.1017. Epub 2018 Feb 1011.

Sala, C., Andreose, J.S., Fumagalli, G., Lomo, T., 1995. Calcitonin gene-related peptide: possible role in formation and maintenance of neuromuscular junctions. J Neurosci 15, 520-528.

Sanchez-Prieto, J., Sihra, T.S., Evans, D., Ashton, A., Dolly, J.O., Nicholls, D.G., 1987. Botulinum toxin A blocks glutamate exocytosis from guinea-pig cerebral cortical synaptosomes. Eur J Biochem 165, 675-681.

Sautter, T., Herzog, A., Hauri, D., Schurch, B., 2001. Transient paralysis of the bladder due to wound botulism. Eur Urol. 39, 610-612. doi: 610.1159/000052513.

Schnaar, R.L., 2016. Gangliosides of the Vertebrate Nervous System. J Mol Biol. 428, 33253336. doi: 3310.1016/j.jmb.2016.3305.3020. Epub 2016 May 3331.

Schnaar, R.L., 2019. The Biology of Gangliosides. Adv Carbohydr Chem Biochem 76:113-148., 10.1016/bs.accb.2018.1009.1002. Epub 2018 Oct 1023.

Schnaar, R.L., Gerardy-Schahn, R., Hildebrandt, H., 2014. Sialic acids in the brain: gangliosides and polysialic acid in nervous system development, stability, disease, and regeneration. Physiol Rev. 94, 461-518. doi: 410.1152/physrev.00033.02013. 
Schulte-Baukloh, H., Zurawski, T.H., Knispel, H.H., Miller, K., Haferkamp, A., Dolly, J.O., 2007. Persistence of the synaptosomal-associated protein-25 cleavage product after intradetrusor botulinum toxin A injections in patients with myelomeningocele showing an inadequate response to treatment. BJU Int 100, 1075-1080.

Scott, A.B., 1981. Botulinum toxin injection of eye muscles to correct strabismus. Trans Am Ophthalmol Soc 79, 734-770.

Shimizu, T., Shibata, M., Toriumi, H., Iwashita, T., Funakubo, M., Sato, H., Kuroi, T., Ebine, T., Koizumi, K., Suzuki, N., 2012. Reduction of TRPV1 expression in the trigeminal system by botulinum neurotoxin type-A. Neurobiol Dis. 48, 367-378. doi: 310.1016/j.nbd.2012.1007.1010. Epub 2012 Jul 1020.

Simpson, L., 2013. The life history of a botulinum toxin molecule. Toxicon. 68, 40-59.

Simpson, L.L., 1981. The origin, structure, and pharmacological activity of botulinum toxin. Pharmacol Rev 33, 155-188.

Simpson, L.L., Rapport, M.M., 1971. Ganglioside inactivation of botulinum toxin. J Neurochem. 18, 1341-1343.

Sloop, R.R., Cole, B.A., Escutin, R.O., 1997. Human response to botulinum toxin injection: type B compared with type A. Neurology 49, 189-194.

Smith, L.A., 2006. Bacterial protein toxins as biological weapons, in: Alouf, J.E., Popoff, M.R. (Eds.), The Comprehensive Sourcebook of Bacterial Protein Toxins, $3^{\circ}$ ed. Elsevier, Academic Press, Amsterdam, pp. 1019-1030.

Smith, T.J., Lou, J., Geren, I.N., Forsyth, C.M., Tsai, R., Laporte, S.L., Tepp, W.H., Bradshaw, M., Johnson, E.A., Smith, L.A., Marks, J.D., 2005. Sequence variation within botulinum neurotoxin serotypes impacts antibody binding and neutralization. Infect Immun 73, 5450-5457.

Smyth, L.M., Breen, L.T., Mutafova-Yambolieva, V.N., 2006. Nicotinamide adenine dinucleotide is released from sympathetic nerve terminals via a botulinum neurotoxin A-mediated mechanism in canine mesenteric artery. Am J Physiol Heart Circ Physiol 290, H1818-1825.

Sobel, J., 2005. Botulism. Clin Infect Dis 41, 1167-1173.

Stenmark, P., Dupuy, J., Imamura, A., Kiso, M., Stevens, R.C., 2008. Crystal structure of botulinum neurotoxin type $A$ in complex with the cell surface co-receptor GT1b-insight into the toxin-neuron interaction. PLoS Pathog 4, e1000129.

Stern, D., Weisemann, J., Le Blanc, A., von Berg, L., Mahrhold, S., Piesker, J., Laue, M., Luppa, P.B., Dorner, M.B., Dorner, B.G., Rummel, A., 2018. A lipid-binding loop of botulinum neurotoxin serotypes $B, D C$ and $G$ is an essential feature to confer their exquisite potency. PLoS Pathog. 14, e1007048. doi: 1007010.1001371/journal.ppat.1007048. eCollection 1002018 May.

Strotmeier, J., Gu, S., Jutzi, S., Mahrhold, S., Zhou, J., Pich, A., Eichner, T., Bigalke, H., Rummel, A., Jin, R., Binz, T., 2011. The biological activity of botulinum neurotoxin type $C$ is dependent upon novel types of ganglioside binding sites. Mol Microbiol 81, 143156.

Strotmeier, J., Lee, K., Volker, A.K., Mahrhold, S., Zong, Y., Zeiser, J., Zhou, J., Pich, A., Bigalke, H., Binz, T., Rummel, A., Jin, R., 2010. Botulinum neurotoxin serotype D attacks neurons via two carbohydrate-binding sites in a ganglioside-dependent manner. Biochem J 431, 207-216. 
Strotmeier, J., Mahrhold, S., Krez, N., Janzen, C., Lou, J., Marks, J.D., Binz, T., Rummel, A., 2014. Identification of the synaptic vesicle glycoprotein 2 receptor binding site in botulinum neurotoxin A. FEBS Lett 588, 1087-1093.

Strotmeier, J., Willjes, G., Binz, T., Rummel, A., 2012. Human synaptotagmin-II is not a high affinity receptor for botulinum neurotoxin $B$ and $G$ : Increased therapeutic dosage and immunogenicity. FEBS Lett 586, 310-313.

Sugawara, Y., Matsumura, T., Takegahara, Y., Jin, Y., Tsukasaki, Y., Takeichi, M., Fujinaga, Y., 2010. Botulinum hemagglutinin disrupts the intercellular epithelial barrier by directly binding E-cadherin. J Cell Biol 189, 691-700.

Surana, S., Tosolini, A.P., Meyer, I.F.G., Fellows, A.D., Novoselov, S.S., Schiavo, G., 2018. The travel diaries of tetanus and botulinum neurotoxins. Toxicon 147, 58-67.

Svennerholm, L., Bostrom, K., Fredman, P., Jungbjer, B., Lekman, A., Mansson, J.E., Rynmark, B.M., 1994. Gangliosides and allied glycosphingolipids in human peripheral nerve and spinal cord. Biochim Biophys Acta. 1214, 115-123. doi: 110.1016/00052760(1094)90034-90035.

Swaminathan, S., 2011. Molecular structures and functional relationships in clostridial neurotoxins. Febs J 278, 4467-4485.

Swaminathan, S., Eswaramoorthy, S., 2000. Structural analysis of the catalytic and binding sites of Clostridium botulinum neurotoxin B. Nature Struct. Biol. 7, 693-699.

Swartling, C., Naver, H., Pihl-Lundin, I., Hagforsen, E., Vahlquist, A., 2004. Sweat gland morphology and periglandular innervation in essential palmar hyperhidrosis before and after treatment with intradermal botulinum toxin. J Am Acad Dermatol 51, 739745.

Tao, L., Peng, L., Berntsson, R.P., Liu, S.M., Park, S., Yu, F., Boone, C., Palan, S., Beard, M., Chabrier, P.E., Stenmark, P., Krupp, J., Dong, M., 2017. Engineered botulinum neurotoxin B with improved efficacy for targeting human receptors. Nat Commun 8 , 53.

Tighe, A.P., Schiavo, G., 2012. Botulinum neurotoxins: Mechanism of action. Toxicon 67, 8793.

Tsukamoto, K., Kohda, T., Mukamoto, M., Takeuchi, K., Ihara, H., Saito, M., Kozaki, S., 2005. Binding of Clostridium botulinum types $\mathrm{C}$ and $\mathrm{D}$ neurotoxins to ganglioside and phospholipid. J. Biol. Chem. 280, 35164-35171.

Umland, T.C., Wingert, L.M., Swaminathan, S., Furey, W.F., Schmidt, J.J., Sax, M., 1997. The structure of the receptor binding fragment $\mathrm{H}_{\mathrm{c}}$ of tetanus neurotoxin. Nature Struct. Biol. 4, 788-792.

Unsworth, C.D., Johnson, R.G., 1990. Acetylcholine and ATP are coreleased from the electromotor nerve terminals of Narcine brasiliensis by an exocytotic mechanism. Proc Natl Acad Sci U S A. 87, 553-557. doi: 510.1073/pnas.1087.1072.1553.

Vajn, K., Viljetic, B., Degmecic, I.V., Schnaar, R.L., Heffer, M., 2013. Differential distribution of major brain gangliosides in the adult mouse central nervous system. PLoS One. 8, e75720. doi: 75710.71371/journal.pone.0075720. eCollection 0072013.

Van Heyningen, W.E., 1961. The fixation of tetanus toxin by ganglioside. J. Gen. Microbiol. 24, 107-119.

Verderio, C., Coco, S., Rossetto, O., Montecucco, C., Matteoli, M., 1999. Internalization and proteolytic action of botulinum toxins in CNS neurons and astrocytes. J Neurochem 73, 372-379. 
Verderio, C., Grumelli, C., Raiteri, L., Coco, S., Paluzzi, S., Caccin, P., Rossetto, O., Bonanno, G., Montecucco, C., Matteoli, M., 2007. Traffic of botulinum toxins A and E in excitatory and inhibitory neurons. Traffic 8, 142-153.

Verderio, C., Pozzi, D., Pravettoni, E., Inverardi, F., Schenk, U., Coco, S., Proux-Gillardeaux, V., Galli, T., Rossetto, O., Frassoni, C., Matteoli, M., 2004. SNAP-25 modulation of calcium dynamics underlies differences in GABAergic and glutamatergic responsiveness to depolarization. Neuron 41, 599-610.

Weise, D., Weise, C.M., Naumann, M., 2019. Central Effects of Botulinum NeurotoxinEvidence from Human Studies. Toxins (Basel). 11(1). toxins11010021. doi: 11010010.11013390/toxins11010021.

Weisemann, J., Stern, D., Mahrhold, S., Dorner, B.G., Rummel, A., 2016. Botulinum Neurotoxin Serotype A Recognizes Its Protein Receptor SV2 by a Different Mechanism than Botulinum Neurotoxin B Synaptotagmin. Toxins (Basel). 8(5). toxins8050154. doi: 8050110.8053390/toxins8050154.

Welch, M.J., Purkiss, J.R., Foster, K.A., 2000. Sensitivity of embryonic rat dorsal root ganglia neurons to Clostridium botulinum neurotoxins. Toxicon 38, 245-258.

Wellhöner, H.H., 1992. Tetanus and Botulinum Neurotoxins, in: Herken, H., Hucho, F. (Eds.), Selective Neurotoxicity. Springer-Verlag, Berlin, pp. 357-417.

Wentz, T.G., Muruvanda, T., Lomonaco, S., Thirunavukkarasu, N., Hoffmann, M., Allard, M.W., Hodge, D.R., Pillai, S.P., Hammack, T.S., Brown, E.W., Sharma, S.K., 2017. Closed Genome Sequence of Chryseobacterium piperi Strain CTM(T)/ATCC BAA-1782, a GramNegative Bacterium with Clostridial Neurotoxin-Like Coding Sequences. Genome Announc 5, e01296-01217pec.

Willjes, G., Mahrhold, S., Strotmeier, J., Eichner, T., Rummel, A., Binz, T., 2013. Botulinum Neurotoxin G Binds Synaptotagmin-II in a Mode Similar to That of Serotype B: Tyrosine 1186 and Lysine 1191 Cause Its Lower Affinity. Biochemistry, 17.

Wonnacott, S., Marchbanks, R.M., 1976. Inhibition by botulinum toxin of depolarizationevoked release of (14C)acetylcholine from synaptosomes in vitro. Biochem J. 156, 701712. doi: 710.1042/bj1560701.

Xiao, L., Cheng, J., Dai, J., Zhang, D., 2011. Botulinum toxin decreases hyperalgesia and inhibits P2X3 receptor over-expression in sensory neurons induced by ventral root transection in rats. Pain Med. 12, 1385-1394. doi: 1310.1111/j.15264637.2011.01182.x. Epub 02011 Aug 01182.

Yao, G., Zhang, S., Mahrhold, S., Lam, K.H., Stern, D., Bagramyan, K., Perry, K., Kalkum, M., Rummel, A., Dong, M., Jin, R., 2016. N-linked glycosylation of SV2 is required for binding and uptake of botulinum neurotoxin A. Nat Struct Mol Biol 23, 656-662.

Yiangou, Y., Anand, U., Otto, W.R., Sinisi, M., Fox, M., Birch, R., Foster, K.A., Mukerji, G., Akbar, A., Agarwal, S.K., Anand, P., 2011. Increased levels of SV2A botulinum neurotoxin receptor in clinical sensory disorders and functional effects of botulinum toxins $A$ and $E$ in cultured human sensory neurons. J Pain Res 4:347-55., 10.2147/JPR.S25189. Epub 22011 Oct 25118.

Yowler, B.C., Kensinger, R.D., Schengrund, C.L., 2002. Botulinum neurotoxin A activity is dependent upon the presence of specific gangliosides in neuroblastoma cells expressing synaptotagmin I. J. Biol. Chem. 277, 32815-32819.

Zhang, S., Berntsson, R.P., Tepp, W.H., Tao, L., Johnson, E.A., Stenmark, P., Dong, M., 2017a. Structural basis for the unique ganglioside and cell membrane recognition mechanism of botulinum neurotoxin DC. Nat Commun 8, 1637. 
Zhang, S., Lebreton, F., Mansfield, M.J., Miyashita, S.I., Zhang, J., Schwartzman, J.A., Tao, L., Masuyer, G., Martinez-Carranza, M., Stenmark, P., Gilmore, M.S., Doxey, A.C., Dong, M., 2018. Identification of a Botulinum Neurotoxin-like Toxin in a Commensal Strain of Enterococcus faecium. Cell Host Microbe 23, 169-176 e166.

Zhang, S., Masuyer, G., Zhang, J., Shen, Y., Lundin, D., Henriksson, L., Miyashita, S.I., Martinez-Carranza, M., Dong, M., Stenmark, P., 2017b. Identification and characterization of a novel botulinum neurotoxin. Nat Commun 8, 14130.

Zhang, Y., Buchko, G.W., Qin, L., Robinson, H., Varnum, S.M., 2010. Structural analysis of the receptor binding domain of botulinum neurotoxin serotype D. Biochem Biophys Res Commun. 401, 498-503. doi: 410.1016/j.bbrc.2010.1009.1063. Epub 2010 Sep 1019.

Zornetta, I., Azarnia Tehran, D., Arrigoni, G., Anniballi, F., Bano, L., Leka, O., Zanotti, G., Binz, T., Montecucco, C., 2016. The first non Clostridial botulinum-like toxin cleaves VAMP within the juxtamembrane domain. Sci Rep 6, 30257. 


\section{Figure legend}

Figure 1. Schematic representation of the innervation of the secretory glands and urinary bladder indicating the main sites of action of BoNT/A.

Secretory glands are innervated by sympathetic/parasympathetic fibers. BoNT/A prevents gland secretion by effecting on cholinergic nerve terminals. Note that sweat glands are innervated only by sympathetic fibers, which are mostly cholinergic, and thus are sensitive to BoNT (denoted as *).

The bladder smooth muscle fibers in the detrusor muscle and smooth muscles fibers in the bladder neck and upper urethra (i.e. internal sphincter) are innervated by sympathetic and parasympathetic fibers. This double innervation controls the contraction (denoted as + ) or relaxation (denoted as -) of the smooth muscle fibers. BoNT/A acts on the parasympathetic cholinergic nerve terminals, and causes inhibition of the release of ACh and co-transmitters (as ATP) decreasing detrusor contraction. In addition, BoNT/A targets sensory fibers (green innervation). This results in a reduced expression of nociceptors such as P2X3 and TRPVI (which are SNARE-dependent), and inhibition of the release of neurotransmitters (glutamate, CGRP, substance P) involved in pain signaling.

Figure 2. Neuronal cell types recognized by BoNT/A (A) or BoNT/B (B) in the mouse intestinal submucosa after administration in the intestinal lumen. Fluorescent BoNT/A, BoNT/B or their recombinant receptor-binding domains were injected into mouse intestinal loops, and after 15 to 30 min the intestinal samples were prepared for histology and were costained with neuronal cell markers. Colocalization index between fluorescent toxin and neuronal markers were determined. BoNT/A and BoNT/B recognize preferentially cholinergic neurons in the intestinal submucosa, to a lower extent serotonergic neurons, and to a much more lower extent the other neuronal cell types. ChAT, choline acetyltransferase (cholinergic neurons); VIP, vaso-intestinal peptide; V-GLUT, vesicular glutamate (glutamatergic neurons); V-GAT, gamma amino butyric acid transporter (GABA neurons); GFAP, glial fibrillary acidic protein (glial cells). Figures were modified from (Connan et al., 2016; Couesnon et al., 2012). 
Figure 1
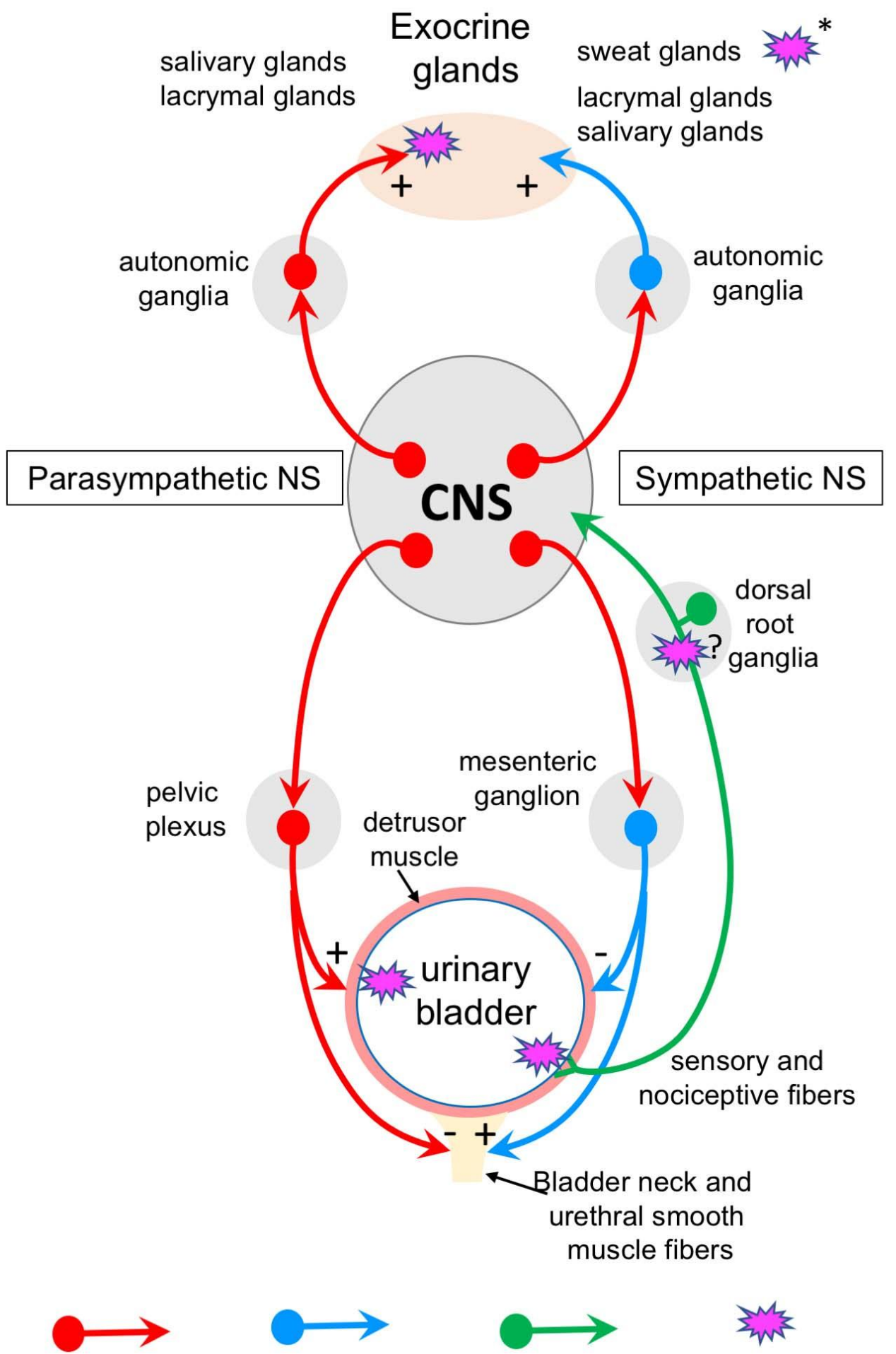
cholinergic adrenergic sensory fiber $\begin{gathered}\text { neurons targeted } \\ \text { by BoNT/A }\end{gathered}$ 
Figure 2

$\mathrm{HcA}$

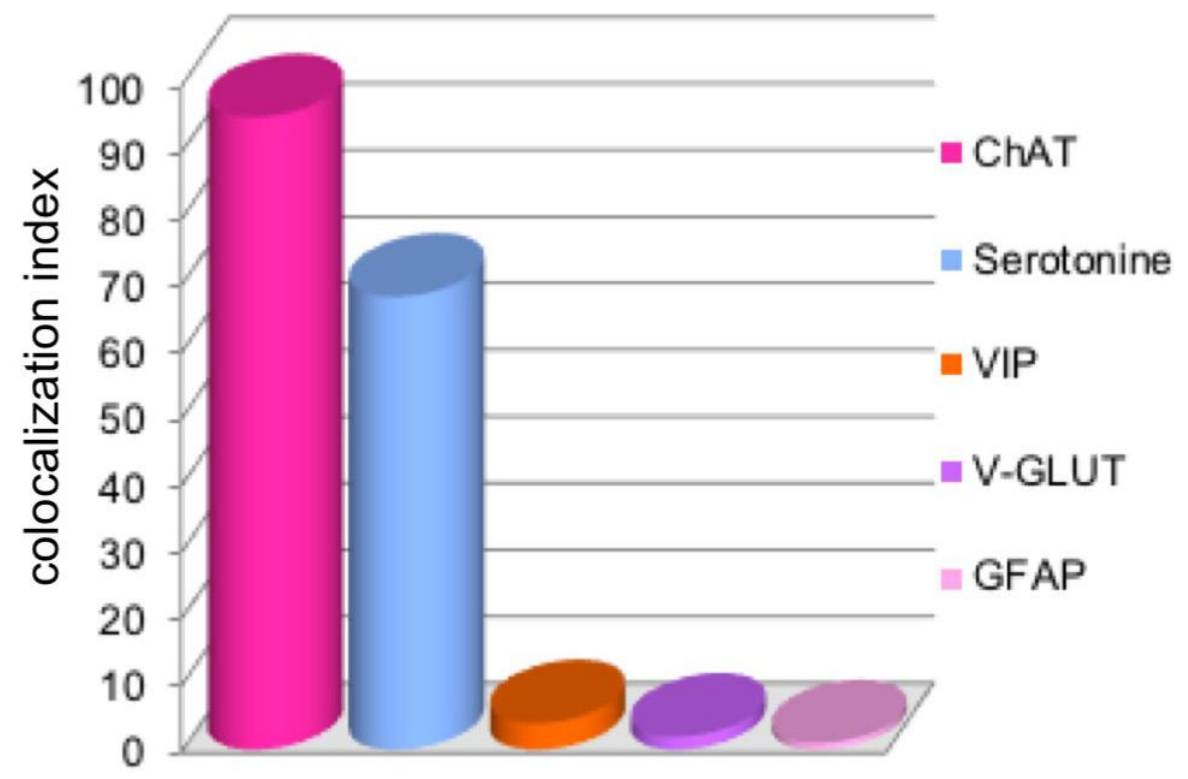

$\mathrm{HcB}$ or BoNT/B

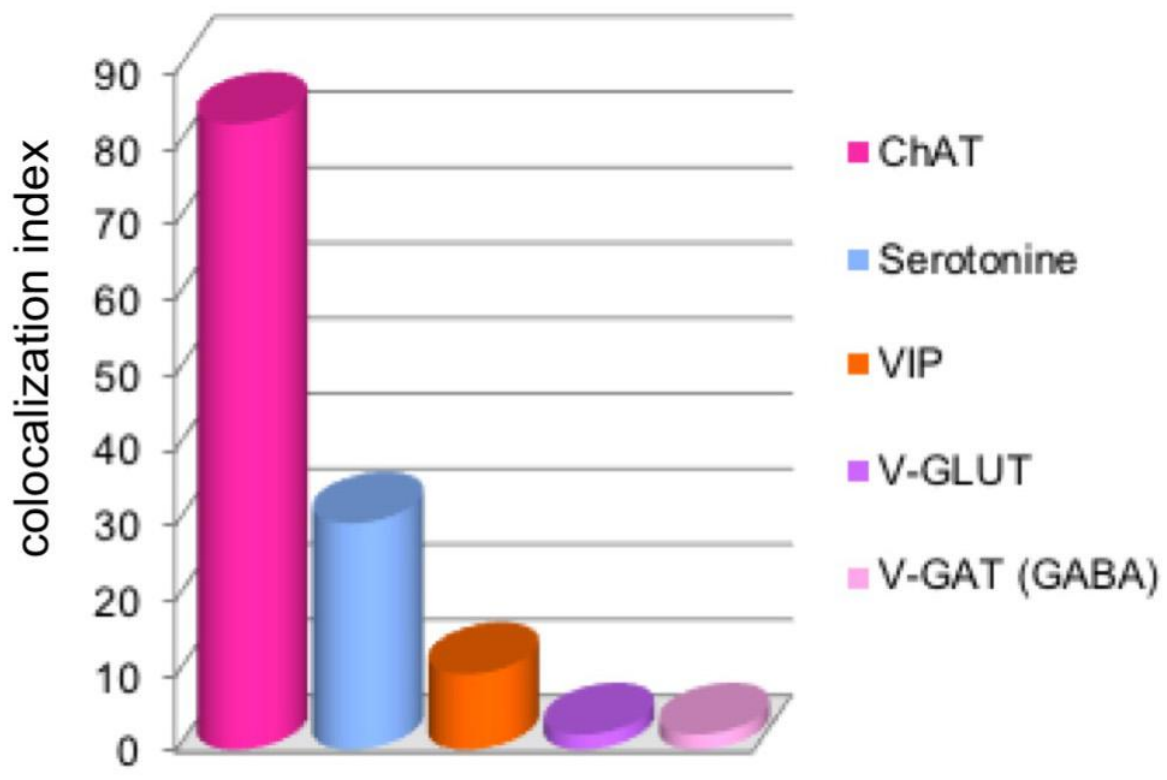


Table 1. Botulinum neurotoxin types, gangliosides and protein receptors.

\begin{tabular}{|c|c|c|c|c|c|c|c|}
\hline BoNT & Ganglioside receptor & $\begin{array}{l}\text { Ganglioside } \\
\text { binding site }\end{array}$ & $\begin{array}{l}\text { Hydrophobic } \\
\text { loop }\end{array}$ & Ref & $\begin{array}{l}\text { Protein } \\
\text { receptor }\end{array}$ & $\begin{array}{l}\text { localization of } \\
\text { the protein } \\
\text { receptor }\end{array}$ & Ref \\
\hline $\mathrm{BoNT} / \mathrm{A}$ & $\begin{array}{l}\text { GT1b }>\text { GD1a, } \\
\text { GD1b }>>\text { GM1 }\end{array}$ & E..H..SXWY..G & & $\begin{array}{l}\text { (Rummel et al., } \\
\text { 2004b; Yowler } \\
\text { et al., 2002) }\end{array}$ & $\begin{array}{l}\text { glycosylated } \\
\text { SV2C } \\
\text { glycosylated } \\
\text { SV2A, SV2B }\end{array}$ & $\mathrm{H}_{\mathrm{CN}} / \mathrm{H}_{\mathrm{CC}}$ & $\begin{array}{l}\text { (Benoit et al., } \\
\text { 2014; Dong et } \\
\text { al., 2008; } \\
\text { Mahrhold et al., } \\
\text { 2013; } \\
\text { Strotmeier et } \\
\text { al., 2014; Yao } \\
\text { et al., 2016) }\end{array}$ \\
\hline $\mathrm{BoNT} / \mathrm{B}$ & $\begin{array}{l}\text { GT1b }>\text { GDIa }> \\
\text { GD1b }>>\text { GM1 }\end{array}$ & E..H..SXWY..G & $\mathrm{H}_{\mathrm{C}}-\mathrm{loop}$ & $\begin{array}{l}\text { (Rummel et al., } \\
\text { 2004b; Stern et } \\
\text { al., 2018) }\end{array}$ & $\begin{array}{l}\text { Synaptotagmin } \\
\text { I } \\
\text { Synaptotagmin } \\
\text { II }\end{array}$ & $\mathrm{H}_{\mathrm{CC}}$ & $\begin{array}{l}\text { (Jin et al., } \\
\text { 2006; Nishiki } \\
\text { et al., 1996; } \\
\text { Rummel et al., } \\
\text { 2007) }\end{array}$ \\
\hline $\mathrm{BoNT} / \mathrm{C}$ & $\begin{array}{l}\text { GD1b, GT1b, GD1a } \\
>\text { GM1a }\end{array}$ & & $\begin{array}{l}\text { WY-loop } \\
\text { Sia-1 }\end{array}$ & $\begin{array}{l}\text { (Karalewitz et } \\
\text { al., 2012; } \\
\text { Karalewitz et } \\
\text { al., 2010; } \\
\text { Kroken et al., } \\
2011 \text { a; } \\
\text { Rummel et al., } \\
\text { 2009; } \\
\text { Strotmeier et } \\
\text { al., 2011; } \\
\text { Tsukamoto et } \\
\text { al., 2005) }\end{array}$ & $?$ & $?$ & \\
\hline BoNT/D & GD2 $>$ GT1b, GD1b & DXY $\ldots V X N$ & & (Kroken et al., & SV2A, SV2B & $?$ & (Peng et al., \\
\hline
\end{tabular}




\begin{tabular}{|c|c|c|c|c|c|c|c|}
\hline & PE & & & $\begin{array}{l}2011 \mathrm{~b} \text {; } \\
\text { Tsukamoto et } \\
\text { al., 2005) }\end{array}$ & & & 2011) \\
\hline BoNT/DC & $\begin{array}{l}\text { GM1a }>\text { GD1a }> \\
\text { GD1b, GT1b }\end{array}$ & & $\begin{array}{l}\text { YWF-loop } \\
\mathrm{H}_{\mathrm{C}} \text {-loop }\end{array}$ & $\begin{array}{l}\text { (Stern et al., } \\
\text { 2018; Zhang et } \\
\text { al., 2017a) }\end{array}$ & $\begin{array}{l}\text { Synaptotagmin } \\
\text { I } \\
\text { Synaptotagmin } \\
\text { II }\end{array}$ & $\mathrm{H}_{\mathrm{CC}}$ & $\begin{array}{l}\text { (Peng et al., } \\
\text { 2012) }\end{array}$ \\
\hline BoNT/E & $\begin{array}{l}\text { GD1a, GQ1b, GT1b } \\
>>\text { GM1 }\end{array}$ & E..K..SXWY..G & & $\begin{array}{l}\text { (Kamata et al., } \\
\text { 1993; Rummel } \\
\text { et al., 2009) }\end{array}$ & $\begin{array}{l}\text { glycosylated } \\
\text { SV2A, SV2B }\end{array}$ & $\mathrm{H}_{\mathrm{CN}} / \mathrm{H}_{\mathrm{CC}}$ & $\begin{array}{l}\text { (Dong et al., } \\
2008 \text {; } \\
\text { Mahrhold et al., } \\
\text { 2013) }\end{array}$ \\
\hline $\mathrm{BoNT} / \mathrm{F}$ & $\begin{array}{l}\text { GT1b, GD1a }>> \\
\text { GM3 >>GD1b, } \\
\text { GM1 }\end{array}$ & E..H..SXWY..G & & $\begin{array}{l}\text { (Fu et al., 2009; } \\
\text { Ochanda et al., } \\
\text { 1986; Rummel } \\
\text { et al., 2009) }\end{array}$ & $\begin{array}{l}\text { SV2A, SV2B, } \\
\text { SV2C }\end{array}$ & & $\begin{array}{l}\text { (Fu et al., 2009; } \\
\text { Rummel et al., } \\
2009 \text { ) }\end{array}$ \\
\hline BoNT/G & $\begin{array}{l}\text { GT1b, GD1a }> \\
\text { GD1b }>\text { GM3 > } \\
\text { GM1 }\end{array}$ & G..G..SXWY..G & $\mathrm{H}_{\mathrm{C}}-\mathrm{loop}$ & $\begin{array}{l}\text { (Fu et al., 2009; } \\
\text { Stern et al., } \\
\text { 2018; Willjes et } \\
\text { al., 2013) }\end{array}$ & $\begin{array}{l}\text { Synaptotagmin } \\
\text { I } \\
\text { Synaptotagmin } \\
\text { II }\end{array}$ & & $\begin{array}{l}\text { (Rummel et al., } \\
\text { 2007; Rummel } \\
\text { et al., 2004a; } \\
\text { Willjes et al., } \\
\text { 2013) }\end{array}$ \\
\hline
\end{tabular}


Table 2. BoNTs block the release of various neurotransmitters from neuronal cells.

\begin{tabular}{|c|c|c|}
\hline Neurotransmitter and neuropeptides & Cell/model system & References \\
\hline Acetylcholine & $\begin{array}{l}\text { Mammals } \\
\text { skeletal muscular junction } \\
\text { urinary bladder } \\
\text { cortical synaptosomes } \\
\text { eye muscles } \\
\text { Fish } \\
\text { torpedo electric organ } \\
\text { Invertebrates } \\
\text { aplysia CNS }\end{array}$ & $\begin{array}{l}\text { (Burgen et al., 1949; Carpenter, 1967) } \\
\text { (Carpenter, 1967) } \\
\text { (Wonnacott and Marchbanks, 1976) } \\
\text { (Scott, 1981) } \\
\text { (Dunant et al., 1987) } \\
\text { (Poulain et al., 1988) }\end{array}$ \\
\hline Glutamate & $\begin{array}{l}\text { Brain synaptosomes } \\
\text { cerebellar granule neurons } \\
\text { sensory nerve terminals in the hindpaw }\end{array}$ & $\begin{array}{l}\text { (Sanchez-Prieto et al., 1987) } \\
\text { (Foran et al., 2003) } \\
\text { (Cui et al., 2004) }\end{array}$ \\
\hline Aspartate & Brain synaptosomes & (McMahon et al., 1992) \\
\hline Gamma amino butyric acid (GABA) & Brain synaptosomes & (Ashton and Dolly, 1988; McMahon et al., 1992) \\
\hline Glycine & Cultured spinal cord neurons & (Neale et al., 1999) \\
\hline $\begin{array}{l}\text { Dopamine } \\
\text { Adrenaline } \\
\text { Noradrenaline }\end{array}$ & Brain synaptosomes & (Ashton and Dolly, 1988; Maisey et al., 1988) \\
\hline Serotonin & Brain synaptosomes & (Najib et al., 1999) \\
\hline Substance P & $\begin{array}{l}\text { Dorsal root ganglia } \\
\text { Urinary bladder explants }\end{array}$ & $\begin{array}{l}\text { (Welch et al., 2000) } \\
\text { (Lucioni et al., 2008) }\end{array}$ \\
\hline Calcitonin gene-related peptide (CGRP) & $\begin{array}{l}\text { Dorsal root ganglia sensory neurons } \\
\text { Trigeminal ganglion sensory neurons } \\
\text { Urinary bladder } \\
\text { Skeletal neuromuscular junction }\end{array}$ & $\begin{array}{l}\text { (Duggan et al., 2002; Welch et al., 2000) } \\
\text { (Durham et al., 2004) } \\
\text { (Lucioni et al., 2008; Rapp et al., 2006) } \\
\text { (Hassan et al., 1994; Meunier et al., 1996; Sala et } \\
\text { al., 1995) }\end{array}$ \\
\hline $\begin{array}{l}\text { Nucleotides } \\
\text { ATP } \\
\beta-N A D\end{array}$ & Urinary bladder & (Breen et al., 2006; Lawrence et al., 2010) \\
\hline
\end{tabular}


